\title{
Investigating the interplays between integrated reporting practices and circular economy disclosure
}

\author{
Federico Barnabè \\ Department of Business and Law, University of Siena, Siena, Italy, and \\ Sarfraz Nazir \\ Department of Economics and Management, University of Pisa, Pisa, Italy
}

\begin{abstract}
Purpose - This study seeks to: (1) discuss how the integrated reporting (IR) framework may provide the principles, concepts and the key elements to support the analysis and representation of circular economy (CE)-related activities and information; (2) explore how and to what extent current IR practices are including and disclosing CE-related information; (3) investigate through an exploratory case study the interplays between $\mathrm{R}$ and CE.

Design/methodology/approach - Building on a theoretical analysis of the interplays between CE and IR, this study first performs textual content analysis on a dataset of 84 integrated reports to determine the type and extent of CE-related disclosure. Subsequently, the article presents and discusses an exploratory case study developed according to an action research perspective.

Findings - Through textual content analysis, the study provides data on CE-related reporting practices for 74 organizations operating worldwide, highlighting differences in reporting choices and emphasizing the role played by IR concepts. Through the exploratory case study, this article provides insights on how IR principles support the analysis and the (re)presentation of CE-related information.

Research limitations/implications - Content analysis is used to explore how and to what extent companies disclose CE-related information, not to investigate the quality of such disclosure. Only one single exploratory case study is used.

Practical implications - This article advocates to embed CE data into integrated reports and according to IR principles. The exploratory case study offers useful insights and examples.

Originality/value - This work represents one of the first studies advocating and exploring the interplays between CE and IR. Additionally, this study aids in the development of a more standardized and established terminology for $\mathrm{CE}$ research and reporting practices.
\end{abstract}

Keywords Circular economy, Integrated reporting, Value creation

Paper type Research paper

\section{Introduction}

This article builds on the current debate (e.g. EEA, 2016; Bourguignon, 2016; UNEP, 2018) on how relevant it is for modern organizations engaging and subsequently communicating in an effective and structured way circular economy (CE) data and information.

In contrast to today's largely linear oriented systems (Millar et al, 2019), "a circular economy represents a development strategy that enables economic growth while aiming to optimize the chain of consumption of biological and technical materials" (EC, 2014b, p. iv). This certainly

(C) Federico Barnabè and Sarfraz Nazir. Published by Emerald Publishing Limited. This article is published under the Creative Commons Attribution (CC BY 4.0) licence. Anyone may reproduce, distribute, translate and create derivative works of this article (for both commercial and non-commercial purposes), subject to full attribution to the original publication and authors. The full terms of this licence may be seen at http://creativecommons.org/licences/by/4.0/legalcode

Received 11 May 2020 Revised 18 August 2020 Accepted 18 August 2020

\section{Integrated reporting and circular economy}

2001 
IJPPM 70,8 entails a deep transformation for organizations as well as consumers, moving from a linearoriented production and consumption system to a system based on exercises aimed at reducing, reusing, remanufacturing and recycling items, thereby excluding or limiting waste (Stahel, 1982; Andersen, 2007). Interestingly, this shift entails not only creating value from waste (e.g. Abuabara et al., 2019) but also managing properly the scarce resources at an organization's disposal and its operational processes and, last but not least, adopting accounting and reporting frameworks to facilitate the integration and subsequent communication of information on systemic and long-term activities (e.g. Geissdoerfer et al., 2017; Kunc et al., 2020a).

Even though reporting practices in the field of $\mathrm{CE}$ are becoming more numerous (e.g. Geissdoerfer et al., 2017), the literature reveals a research gap in this area (e.g. Korhonen et al., 2018a) since no specific reporting standard and tailored measurement tools have been developed yet or are still at a pioneering stage (e.g. Ellen MacArthur Foundation, 2015a). Previous research (e.g. see Korhonen et al., 2018b) also emphasized that CE practices lack a common underlying language, to the point that even a basic glossary of concepts is not existing, shared and/or applied worldwide. Overall, these factors facilitate heterogeneous forms of CE management, measurement and disclosure practices (e.g. Elia et al., 2017; Svensson and Funck, 2019; Ünal et al., 2019), spanning from qualitative to quantitative documents, based on a number of quite different reporting tools and techniques (e.g. Garza-Reyes et al., 2019a).

Starting from these considerations, this article advocates an increased role for integrated reporting (IR) practices (IIRC, 2013a) for the analysis and disclosure of CE-related data. Based on the integrated reporting framework (IIRC, 2013a), IR has emerged not only as one of the latest innovations in the field of corporate and sustainability reporting (e.g. Eccles and Krzus, 2011; Adams, 2015; Atkins et al, 2015a; Dumay et al, 2016; Busco et al, 2018) but also as a potentially good fit for organizations interested in representing holistically and comprehensively CE-related information (Stewart and Niero, 2018; Kunc et al., 2020a). As we will discuss more extensively in Section 2, the IR Framework (IIRC, 2013a) is rooted on four categories of elements (inputs, business activities, outputs, and outcomes), which are to be considered as the fundamental building blocks for any business model and valuecreation system and are connected circularly by a feedback-oriented mechanism. Overall, $\mathbb{R}$ has the potential to play a relevant role both for the external disclosure of $\mathrm{CE}$ information and, internally, as a support for the analysis and management of the scarce resources at disposal.

With this said, this article has three main aims:

(1) Discuss how the IR framework may provide the principles, concepts and key elements to support the analysis and representation of CE-related activities and information;

(2) Explore how and to what extent current IR practices are including and disclosing CErelated information;

(3) Investigate through an exploratory case study the interplays between IR and CE.

The first two aims are addressed not only from a theoretical point of view - i.e. reviewing the relevant literature and developing a model able to emphasize the similarities and the interplays between IR and CE -, but also performing content analysis (Krippendorff, 2004) with the N-Vivo 12 Pro software within a dataset that included 84 integrated reports. Subsequently, the third aim of the article is addressed with the presentation of an exploratory case study (Ryan et al., 2002) about a company that is a world leader in the paper recycling industry where it also provides waste management services.

The manuscript is structured as follows. Section 2 presents some considerations about the concept of $\mathrm{CE}$ and the key strengths of the IR Framework for the analysis and the disclosure of CE-related information. Section 3 presents the research design, while Section 4 reports the key results of the content analysis and presents the case study. Section 5 provides our discussion, followed by some limitations to this study and ideas for future research. 


\section{Literature review on circular economy and integrated reporting for circular economy}

\subsection{The concept of circular economy}

The literature provides several definitions for the term "Circular Economy" (e.g. Kirchherr et al., 2017 analyzed 114 definitions of CE; Moraga et al., 2019 provided definitions of CE both sensu stricto and sensu latu, thereby discussing the boundaries of this concept) and recognizes that it may be addressed relying on various perspectives derived from different disciplines, at the point that it is still seen as "a contested concept" (Korhonen et al., 2018a) fueling a lively debate at different levels (e.g. academia and business world-Korhonen et al., 2018b). Within this context, research on CE has been steadily increasing for the last decade, and a few general frameworks presenting the concept and its core operational elements can be found in the scientific (e.g. Mihelcic et al., 2003), business (e.g. Ellen MacArthur Foundation, 2014) and the institutional world (e.g. EC, 2014a; UNEP, 2018).

In this study, we look at a $\mathrm{CE}$ as an economic system where products and services are traded in closed-loop cycles, in contrast with the linear-oriented system that has traditionally characterized our production processes (so-called "linear economy", Millar et al., 2019). A CE is seen as an economy that is regenerative by design, in order to retain as much value as possible of products, parts and materials (Ellen MacArthur Foundation, 2013) thereby reducing or eliminating waste. Subsequently, the ultimate goal is to create a system that allows for longer life of resources, optimal reuse, refurbishment, remanufacturing and recycling of products and materials (Ellen MacArthur Foundation, 2013, 2015b; Kraaijenhagen et al., 2016).

As its name suggests, the key to the $\mathrm{CE}$ is the feature of circularity, conveyed by the concept of "feedback loop" (Richardson, 1999). A feedback loop is formed when two or more variables are circularly connected, e.g. A affects $B$, then $B$ affects $C$ and ultimately $C$ affects $A$, thereby closing the loop and determining a circular relationship between A-B-C (Sterman, 2000). This is even more relevant when we consider supply chain context, i.e. domains where multiple agents (e.g. dealers and customers) commerce through the planning and control of materials and information (Golroudbary and Zahraee, 2015) thereby creating a network of interrelationships and feedback loops to be first identified and, subsequently, managed and exploited. However, as emphasized by Sterman (2000, p. 12) it is challenging "discovering and representing the feedback processes, which, along with stock and flow structures, time delays, and nonlinearities, determine the dynamics of a system".

In broad terms, a CE can be viewed and designed as a circular framework dependent on, at least, four closed loops (see Figure 1) [1]:

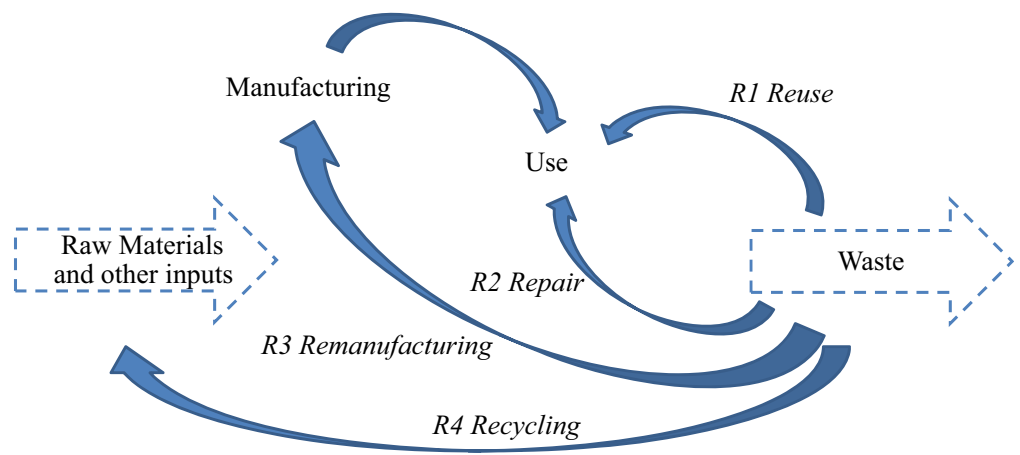

Source(s): Adapted from Stahel, 1982
Integrated reporting and circular economy

2003
Figure 1. Key operations and loops in a $\mathrm{CE}$ 
IJPPM

70,8

2004
(1) Reusing (loop1 1),

(2) Repairing (loop 2),

(3) Remanufacturing (loop 3),

(4) Recycling (loop 4).

According to this framework, interrelationships within a $\mathrm{CE}$ are characterized by flows of materials moving not only downstream but also upstream and - more importantly - in closed loops (Golroudbary and Zahraee, 2015). Within this context, the ultimate challenge for modern organizations is to design a self-renewing economy that limits matter, energy flow and ecological strain without limiting economic, social and technological development (Andersen, 2007) and complete the shift from the linear to a circular (closed-loop) system (Millar et al., 2019. This will likely require to rethink the production processes in use and to evolve the business models once adopted (Lüdeke-Freund et al., 2019; De Sousa Jabbour et al., 2019). As shown by Figure 1, in the reasoning of CE, the traditional linear-oriented model of inputs-operations-outputs and waste is now replaced by a model where unused does not exist and waste is to be reduced and treated to generate new value - being reused, repaired, remanufactured or recycled (see the loops from R1 to R4 in Figure 1). Interestingly, Figure 1 also demonstrates the exercises of the life-expansion frameworks within longer feedback loops that involve multiple actors within the same domain or supply chain.

Although quite new as a concept, previous research already demonstrated both the motivations that could justify and inform CE-related strategies and the potential benefits that could be gained consequently. As to the motivations, various studies (e.g. Park et al., 2010; Ieng Chu et al., 2013; Murray et al., 2017; Korhonen et al., 2018b; DeLorenzo et al., 2019) highlighted that organizations engage with $\mathrm{CE}$ for several reasons, such as establishing legitimacy, adopting isomorphic behaviors (for example, if compared to the competitors or the global context), adhering to institutional regulations and providing an increased disclosure to specific categories of stakeholders. Notably, these motivations are similar to the ones emphasized in other studies that analyzed sustainability-related strategies and reporting practices for modern organizations (e.g. Kozlowski et al., 2015; Baret and Helfrich, 2019). As to the benefits, previous research (e.g. Park et al., 2010) demonstrated that a CE can certainly provide both short-term and long-term benefits (but also some limitations-e.g. Korhonen et al., 2018b). Certainly, one of the key strengths of the approach lies in its multidimensional nature: $\mathrm{CE}$ is a concept that goes beyond the borders of a single organization or an industry and cannot be limited only to raw materials and waste or to the economic dimension of our society. A CE specifically aims to regenerate and reuse capital, whether this is financial, manufactured, human, social or natural (Ellen MacArthur Foundation, 2013), and this process is directed toward the generation of wealth and for wellbeing at the highest level possible. Stated differently, nowadays, the concept of CE is frequently associated with the ideas of sustainability and sustainable development (Corona et al., 2019; Nouri et al., 2019a), and the challenges it raises are increasingly embraced by companies, associations and regulators all over the world (e.g. Flynn and Hacking, 2019). These organizations are expected to identify how $\mathrm{CE}$ processes work in practice and subsequently disclose and communicate adequately data and information about CE-related strategies, actions and results to all the relevant stakeholders (e.g. see DeLorenzo et al., 2019) that, in turn, will pressure those organizations to disclose better information and adopt more structured and effective CE-related practices and strategies (Jakhar et al., 2019). To our knowledge, the state of the art in this field reveals that neither a common standard (or framework) for the disclosure of $\mathrm{CE}$ information nor a commonly recognized and shared glossary of CE concepts used for reporting exists worldwide (e.g. see Korhonen et al., 2018a), thereby calling for more research and evidence in this area. 


\subsection{Circular economy reporting and the potentials of integrated reporting}

The considerations aforementioned and several calls from the academia, regulators and other stakeholders engaged in the debate about CE (e.g. see EEA, 2016 and Deloitte, 2017) witness the necessity of analyzing and producing more data, indicators and measures about CE activities and impacts (e.g. see Elia et al., 2017; Geng et al., 2012; Corona et al., 2019; Moraga et al., 2019; Kristensen and Mosgaard, 2020) and of identifying proper reporting frameworks and tools to be employed accordingly. In this context, a lively debate is pointing to the role that integrated forms of reporting (Abeysekera, 2013; Ellen MacArthur Foundation, 2013) should play. A comprehensive and integrated approach to managing and reporting $\mathrm{CE}$ information would entail not only to communicate data about the resources being used, the activities carried out, the results achieved and the impacts generated (Ellen MacArthur Foundation, 2015a) but also to identify, reveal and disclose the interconnections and the feedback loops active among the elements aforementioned within an organization's CE-oriented strategy (e.g. Kunc et al., 2020a).

Within this debate, this study places specific emphasis on the potentials of the "Integrated Reporting (IR) Framework" (IIRC, 2013a). Developed by the International Integrated Reporting Council (an international coalition of regulators, investors, companies, standard setters, accounting professionals and NGOs) IR has emerged as a powerful tool in the field of sustainability corporate reporting and also as a potential fit for the organizations interested in disclosing CE-related information (Rodríguez-Gutiérrez et al., 2019; Kunc et al., 2020a). One of the reasons underlying this proposal builds on the fact that when disclosing CE-related information - if compared to traditional financial reporting - organizations tend to rely more on principle-based reporting frameworks than on normative or prescriptive ones (Velte and Stawinoga, 2017). At the same time, CE and IR reporting practices also tend to rely more on narrative, visual and textual information rather than on numerical data (Abeysekera, 2013; Busco et al., 2013; Barnabè et al., 2019). Whereas previous research already demonstrated that IR is increasingly used to embed and communicate environmental, social and financial information (e.g. Eccles and Krzus, 2011; Beattie and Smith, 2013; Busco et al., 2013; Atkins et al., 2015b; Adams, 2015, 2017; De Villiers and Sharma, 2020), its use to analyze and disclose effectively data about $\mathrm{CE}$ activities is still under-researched, thereby calling for more investigation and evidence (e.g. Kamp-Roelands, 2013; Stewart and Niero, 2018; Dewick et al., 2020; Di Vaio et al., 2020). The motivations behind this gap may be due to the relative novelty of $\mathrm{CE}$ reporting practices as well as to the existence of an under-researched linkage between CE and IR (Kunc et al., 2020a), which is subsequently addressed in this study.

\subsection{Integrated reporting for circular economy}

Integrated reporting aims to assist companies of different sizes, entity and geographical areas to develop their corporate reports with an integrated and holistic perspective.

To this aim, over the last few years, IIRC has issued not only a key-reference framework (i.e. "The International $<\mathrm{IR}>$ Framework-IIRC, 2013a) but also several other documents (e.g. IIRC, 2016) and papers (e.g. background papers-see IIRC, 2013b, c, d) to present the guiding principles, the content elements and the value creation process at the basis of the idea of integrated reporting and integrated thinking.

IR does not require organizations to disclose exclusively financial information and numerical data, rather it encourages them to communicate nonfinancial information as well as to add narrative and visuals atop of the quantitative data to increase and facilitate the representation and the disclosure of information, thereby telling "their unique value creation story" (Druckman, 2017, p. 23).

Notably, IR is conceived as a principle-based approach and not as a normative or prescriptive one (Velte and Stawinoga, 2017). Therefore, IR supports organizations in their effort of drafting a report with the help of a core set of guiding principles (e.g. strategic focus and future orientation and connectivity of information - see IIRC, 2013a).

\section{Integrated reporting and circular economy}

2005 
IJPPM 70,8

\section{6}

Specifically, at the core of an integrated report and the value creation process it addresses lies an organization's specific business model (Figure 2).

According to IIRC (2013a, p. 13), the business model is characterized by four groups of key elements, i.e. inputs, business activities, outputs and outcomes. These elements are interconnected since, in the beginning, the organization acquires its capitals or inputs (six categories are identified, as depicted in Figure 2, i.e. financial, manufactured, intellectual, human, social and relationship and natural) and then converts them into outputs (key products, services, by-products, and waste) through business activities. The final phase of the process determines outcomes (either internal - e.g. employee morale or external - e.g. customer satisfaction and social and environmental impacts) that affect the initial situation, causing the regular review of the entire model (IIRC, 2013b, p. 6). An organization creates value over the short-, medium- and long-term (IIRC, 2013a, c; Beattie and Smith, 2013; Busco et al., 2013; Adams, 2015; Giorgino et al., 2019):

(1) Using internal factors and exploiting the capitals/resources available;

(2) Managing the interdependencies among such capitals/resources;

(3) Interacting with the external environment and through relationships with other stakeholders;

(4) Managing and exploiting the feedback-oriented processes that underpin the process of value creation in IR (bottom part of Figure 2) and also impact on single processes or capitals over time. This is particularly relevant since it conveys the feature of circularity to IR-based processes and practices.

Notably, in IR the holistic approach to an organization's processes of value creation is directly emphasized by the underlying principle of "Integrated Thinking" (IIRC, 2013a; Adams, 2017; Guthrie et al., 2017; McNally et al., 2017; Busco et al., 2017) which can be defined as "the active consideration by an organization of the relationships between its various operating and functional units and the capitals that the organization uses or affects" (IIRC, 2013a, p. 2). In the

Figure 2.

IR functioning: capitals, core elements and value creation process

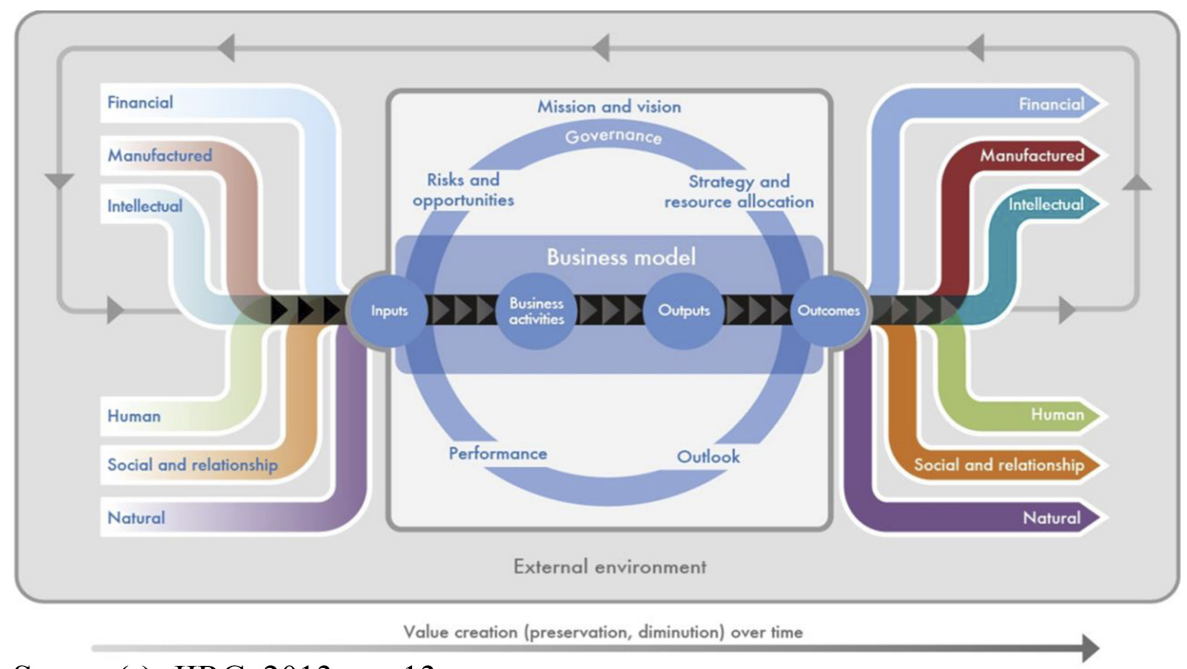

Source(s): IIRC, 2013a, p. 13

"With permission from the International Integerated Reporting Council 2020 (C)" 
end, the overall process of value creation can be considered positive (if outputs and outcomes generate a net increase in a capital and, subsequently, create value) or negative (value diminishes).

With this said, whereas previous literature already addressed how IR may support organizations in managing and reporting on sustainability-related issues (e.g. Eccles and Saltzman, 2011; Beattie and Smith, 2013; Dumay et al., 2016; Giorgino et al., 2016; Stacchezzini et al., 2016; De Villiers and Sharma, 2020), a research gap is existing in terms of adopting and tailoring IR principles and tools to report and organize CE-related concepts and information (with few examples available, however calling for more research-e.g. Kunc et al., 2020a).

In this regard, we believe that the IR Framework may offer a perfect fit for the organizations engaged by $\mathrm{CE}$ for several reasons (see Figure 3).

First, IR and CE build on the concept of "capitals", i.e. the key resources at an organization's disposal. According to the IR terminology (IIRC, 2013d, p. 2), the term capital "refers broadly to any store of value that an organization can use in the production of goods or services". In both cases (IR and CE), capitals are seen and serve as intertwined inputs to all the operations, with the goal to create value over time. As portrayed in Figure 2, the IR framework lists six categories of capitals and considers waste as an output of the process, while CE looks at a number of possible inputs (mostly raw materials) and considers waste as a potential source of "new" value since it should be reused (R1), repaired (R2), remanufactured (R3) or recycled (R4) in new production processes.

Second, both IR and CE explicitly look at value creation as a process taking place over time. This entails considering a process-oriented and dynamic perspective and adopting the idea that the results of our actions need to be monitored and reported over time (the short-, medium- and long-term).

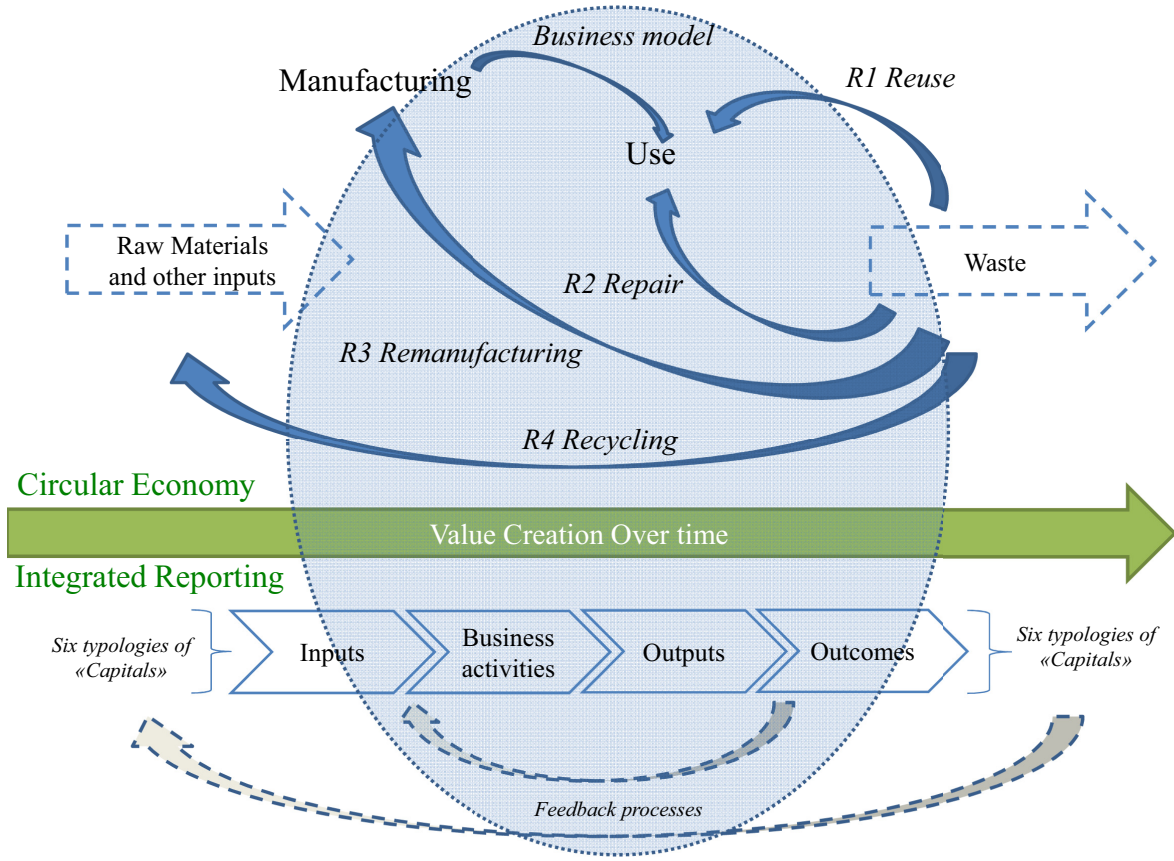

Integrated reporting and circular economy

2007 
IJPPM 70,8

Third, both IR and CE look at value creation as an integrated closed-loop system: inputs become outputs and outcomes that eventually feedback on the inputs (i.e. the capitals). More specifically, CE is rooted in the concept of closed-loop, strongly advocating for a paradigm shift from a linear-oriented economy toward a closed-loop approach to management and reporting (e.g. see Ellen MacArthur Foundation, 2014; Millar et al., 2019; Garza-Reyes et al., 2019b). The four loops from R1 to R4 displayed in Figure 3 emphasize this feature. On the other side, the framework promoted by IIRC (IIRC, 2013a) explicitly conveys a feedback-loop orientation to IR, which underpins the whole value creation process and entails managing simultaneously the six categories of capitals at disposal as well as their interplays and tradeoffs (Kunc et al., 2020a). Additionally, as displayed in Figure 3 which provides a simplification of this reasoning (just two loops are represented), feedback processes may also be generated by the interplays by the groups of elements within an organization's business model (e.g. outputs and business activities -Giorgino et al., 2019).

Fourth, relevant is the fact that both approaches focus on the business model as the core of an organization's strategies and operations. Therefore, the two models share the same reasoning when coming to the representation of the business model, which is built and exploits the complex hierarchy of connections among an organization's inputs, operations (the business activities), outputs and outcomes, as well as all the web of loops that might exist among such elements. This common feature is portrayed in Figure 3 by the dashed circle identifying the business model across the two approaches (i.e. CE and IR).

Additionally, both IR and CE builds on an idea of integration and connectivity among the resources, processes and agents acting within the specific business domain under analysis, More specifically, the principle of "integrated thinking" which underpins the IR approach can be effectively applied also to $\mathrm{CE}$ since it implies that the decision-making process of any organization has to consider all the interrelationships existing across its business units, functions and resources (IIRC, 2013a; Kunc et al., 2020b).

Last, both approaches strive for the highest possible value creation that could and should be pursued reducing negative external impacts (e.g. emissions) of the operations and through the reduction (or, at least, careful consideration) of waste and unused.

With this said, the following section presents the research design underpinning our study.

\section{Research design}

The research design entailed first searching for CE-related concepts relying on IR documents as our primary source and on the integrated reporting framework (IIRC, 2013a) as the underlying theoretical point of reference for the (re)organization of the results. Subsequently, we developed an exploratory case study according to an action research design. More details are provided below.

The CE-related concepts were searched through textual content analysis (Krippendorff, 2004) performed using the N-Vivo 12 Pro software and a specific codebook of concepts (a complete record of terms, i.e. a glossary-Neuendorf, 2002) defined ex ante (Schilling, 2006). Content analysis is "a research technique for the objective, systematic and quantitative description of the manifest content of communication" (Berelson, 1952) and can be used with either qualitative or quantitative data thereby allowing organizing "the text of writing into various groups or categories based on selected criteria" (Guthrie et al., 2004, p. 287). Notably, content analysis has been already employed in the field of $\mathrm{CE}$, e.g. to investigate on the various possible definitions and interpretations associated with the concept of $\mathrm{CE}$ (e.g. Geissdoerfer et al., 2017; Kirchherr et al., 2017; McDowall et al., 2017). In this study, we used textual content analysis to determine the type and extent of disclosure for CE-related information investigating 84 integrated reports (retrieved on the date August 28, 2019), drawn-up by 74 organizations (Table A1 of the appendix provides the full list) belonging to 13 
different industries (i.e. basic materials, consumer goods, consumer services, financial services, healthcare, industrials, professional services, public sector, oil and gas, real estate, technology, telecommunications and utilities) and from six geographic regions (i.e. Europe, South America, North America, Asia, Africa and Australasia). The reports cover an eightyear time horizon, being drafted from 2011 to 2018. Our primary source was the public IIRC database (The Integrated Reporting Examples Database-available at http://examples. integratedreporting.org/home) that contains examples of practices in IR illustrating how organizations are currently reporting - or have reported - data and information about their strategy, governance and performance. This database has been recognized and employed as a reliable source of data by previous studies (e.g. Dumay et al., 2017; Zhou et al., 2017; Velte and Stawinoga, 2017; Pistoni et al., 2018). We selected this source due to the inclusion of reports that adhere closely to the IR guiding principles, content elements and fundamental concepts, thereby being aligned to our theoretical framework.

To perform textual content analysis, given the lack of a standardized glossary for CEconcepts at a global level, we first retrieved one of the fewest lists officially available, i.e. the "Glossary of Circular Economy" (downloaded at https://www.uschamberfoundation.org/ circular-economy-toolbox/about-circularity/glossary). This list of terms is developed by the US Chamber of Commerce, which is the world's largest business organization representing the interests of millions of businesses of all sizes, sectors and regions. Furthermore, to widen the glossary, thereby avoiding rooting our analysis on a list primarily applied in one geographical area, we used additional terms, selected by the two researchers applying a basic brainstorming method (Wilson, 2013) as well as synonyms (created by the N-Vivo 12 Pro software for each of the terms previously identified). The glossary, which initially included 56 terms, was afterward expanded to 98 concepts, which guided the content analysis with $\mathrm{N}$ Vivo. The results of the content analysis were grouped into the four categories of elements defined by the IR framework (IIRC, 2013a)-i.e. inputs, business activities, outputs and outcomes.

Subsequently, we carried out an exploratory case study according to an action research design. The potentials and strengths of case studies (Eisenhardt, 1989; Yin, 1994) to explore and explain how management accounting in practice works - both in terms of the techniques, procedures and systems which are used and how they are used - are recognized by a wide literature (e.g. Scapens, 1990). In detail, exploratory case studies (Ryan et al., 2002, p. 144) are used in the field of accounting and management with the purpose not only of exploring the reasons for particular accounting practices but also of generating hypotheses about those reasons. Therefore, this kind of case study allows preliminary investigations that may support subsequently the generation of ideas and hypotheses to be tested more rigorously at a later stage. In detail, this paper focuses on a company that provides integrated recycling and waste management services, i.e. Paper Mill Ltd. (this is the disguised name of the company). We believe that the business case is a peculiar one since this industry is at the core of the CE movement and entails not only a definite collaboration among the various actors operating along the supply chain (several actors operating within a closed-loop supply chain-e.g. Tajbakhsh and Hassini, 2015; Kazemi et al., 2019) but also an effort toward the disclosure and communication of integrated data and information. In this context, this study emphasizes the opportunity of using IR concepts and practices, specifically with an action research approach (Lewin, 1946). In detail, previous research demonstrated that action research is particularly powerful in facilitating co-operation, participation, interaction and dialog between researchers and practitioners (Wicks and Reason, 2009), thereby facilitating the development of new ideas, practical knowing (Reason and Bradbury, 2001) and also ad hoc solutions (Dresch et al., 2015) both during the intervention and as a result of it.

About the sources used to develop the case study, we relied on multiple data collection methods to increase the validity and reliability of this study through triangulation (Patton,
Integrated reporting and circular economy

2009 
IJPPM 70,8

1987). Specifically, the data were collected through written documents, interviews and informal discussions. Written documents include the company's annual reports as well as a number of other documents and reports publicly available. The interviews were conducted with the top manager of one of the company's branches and with the engineer in chief of the branch's internal operations. Formal discussions were carried out with several employees during a visit to the company and during two internal meetings devoted to discussing operational as well as safety procedures and issues within the company.

\section{Results}

\subsection{Results from the content analysis}

Table 1 describes the dataset used to perform content analysis, particularly highlighting the distribution of the 84 integrated reports per industry, region and year. Notably, all these categories and information were retrieved from the IIRC website and were considered of interest in investigating CE-related reporting practices over time (years), space (regions) and according to a cross-sector perspective (industries).

As shown in Table 1, the 84 reports were drafted by organizations operating in six regions of the world (mostly, Europe and Africa), 13 different industries (the most represented are financial services, basic materials, consumer services and industrials) and cover a time horizon of eight years (from 2011 to 2018, with an increase in the last two years for which integrated reports were available at the time of the analysis, 2017 and 2018).

1.611.522 terms of interest for this study (concepts, and synonyms) were identified by the software when searching the dataset. Specifically, Table 2 presents the total number of concepts classified per industry, region and year of the reports.

The concepts identified by the software were subsequently divided and grouped (i.e. "reclassified") according to the four main categories of the fundamental elements theorized by the IIRC Framework (IIRC, 2013a), i.e. inputs, business activities, outputs and outcomes (see Table 3) and for any major characteristic of the dataset (i.e. industry, region and year). Whereas Table 3 provides an aggregated view of the results obtained with N-Vivo, the appendix (Tables A2-A4) shows the results in more detail, thereby allowing to identify similarities and differences in terms of the use and disclosure of CE-related terms. Specifically, we provided the number of counts as well as the mean and standard deviation values for the concepts aforementioned.

With this said, we can now consider the third aim of this article.

\subsection{Results from the case study}

The considerations and data we provided about CE and IR disclosure practices as well as their interplays were helpful to organize and develop an exploratory case study with an action research perspective.

Paper Mill Ltd. (the disguised name for this organization) is a leading company that operates providing integrated recycling and waste management services, specifically offering corrugated packaging solutions. In addition to virgin raw materials, the company recycles cardboard and other paper-made waste that are subsequently treated and remanufactured to generate packaging products for the market. Overall, the company aims to "do more with less", and has embraced the challenge of CE for some years to date, with the ambitious goal of remanufacturing recycled materials to "generate" value and zero waste.

The company is a relevant player within a longer supply chain centered on recycling waste that is regenerated into new products that are customized for the customers. These two different "roles" of Paper Mill Ltd. are relevant for this study, as described subsequently 


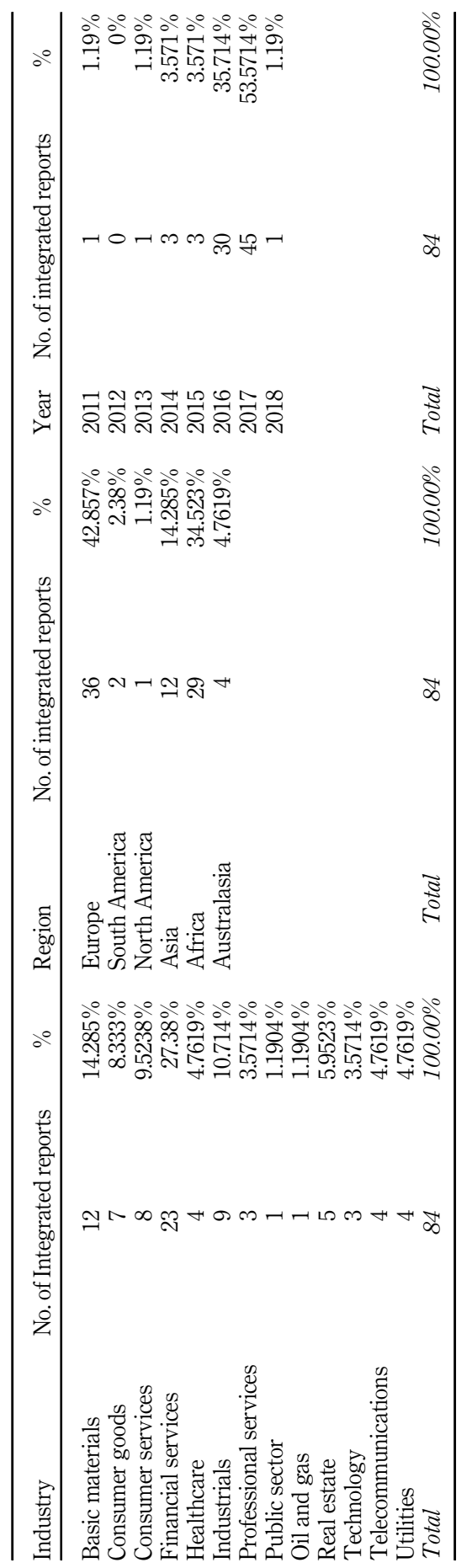

\section{Integrated reporting and circular economy}

2011

Table 1. Characteristics of the dataset analyzed in this study (no. of reports per industry, region and year) 


\section{IJPPM \\ 70,8}

2012

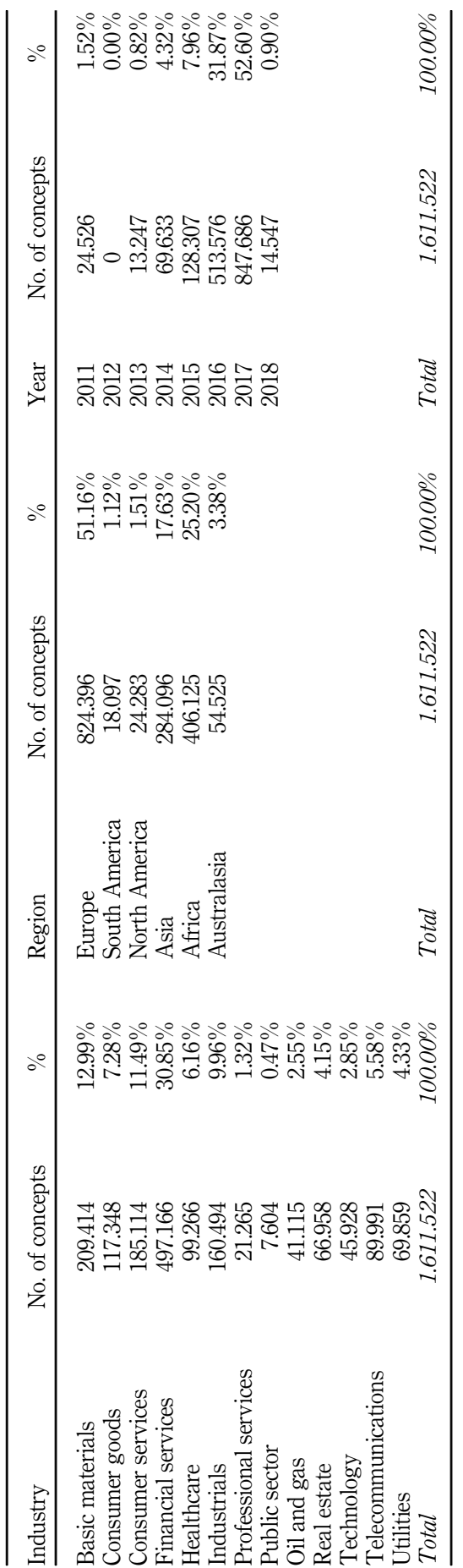

Table 2.

CE-related concepts identified with content analysis, classified per industry, region and year 


\begin{tabular}{|c|c|c|c|c|}
\hline Categories & Concepts & No. & $\%$ & \\
\hline Inputs & $\begin{array}{l}\text { Alternate material, automation, building, capital and capitals, } \\
\text { coordination, dematerialization, ecosystem service, equipment, funding } \\
\text { model, funding, green financing, greenhouse gases, human capital or } \\
\text { human capitals, human, infrastructure, intellectual capital, intellectual } \\
\text { property, investment, financial, manufactured, natural, people, raw } \\
\text { material sourcing, raw material, reassembled, relationships, sharing, } \\
\text { social, transport }\end{array}$ & 28 & $28.57 \%$ & $\begin{array}{l}\text { circular } \\
\text { economy }\end{array}$ \\
\hline $\begin{array}{l}\text { Business } \\
\text { activities }\end{array}$ & $\begin{array}{l}\text { Activities, after-sale service, after sale, control, conversion, data } \\
\text { management, design, development, differentiation, distribution, } \\
\text { durability, joint venture, management, market segmentation, operational } \\
\text { improvement, planning, production, quality control, quality, relationship } \\
\text { management, research, responsible sourcing, sale, service provider, } \\
\text { service provision, take back }\end{array}$ & 26 & $26.53 \%$ & \\
\hline Outputs & $\begin{array}{l}\text { Basic material, by-product, closed loop, end of life, product life cycle, } \\
\text { product life, product service system, products, recycle, redesign, } \\
\text { refurbishment, remanufacturing, renewable resource, renewable, resource, } \\
\text { service, utility, waste conversion, waste diversion, waste }\end{array}$ & 20 & $20.41 \%$ & \\
\hline Outcomes & $\begin{array}{l}\text { Asset consumption, assets recover after consumption, carbon footprints, } \\
\text { consumption, contribution to local economy through taxes, customer } \\
\text { satisfaction, customers, employee development, employee engagement, } \\
\text { employee, impact, improved standard of living, job creation, lease, license } \\
\text { to operate, living, environment, loss, packaging, profit, shareholder } \\
\text { returns, shareholder, stakeholder, taxes, worker training }\end{array}$ & 24 & $24.49 \%$ & $\begin{array}{l}\text { CE-related concepts } \\
\text { included in the } \\
\text { glossary and their } \\
\text { reclassification } \\
\text { according to the main } \\
\text { categories of elements } \\
\text { provided by the IR }\end{array}$ \\
\hline Total & & 98 & $100 \%$ & framework \\
\hline
\end{tabular}

(Figure 4). Specifically, the case study started analyzing and discussing with the manager and the chief engineer of one of the company's branches the role of Paper Mill Ltd. within its supply chain as well as the main operations carried out internally by the company. To summarize this information, and according to an action research design, the authors first developed an aggregated representation of the company's external and internal environment in the form of a subsystem diagram (Sterman, 2000; see Figure 4) and subsequently analyzed the company's annual reports with the lenses of integrated reporting to draw a second subsystem diagram (Figure 5).

In broad terms, subsystems diagrams show the overall architecture of a model (or a map or a system) and are particularly useful since they convey information on the boundaries and level of aggregation in such domain. Additionally, these diagrams are useful since they provide and communicate information about the endogenous and exogenous variables operating in the context under investigation (Sterman, 2000).

The diagram represented in Figure 4 clarifies which are the main operations of Paper Mill Ltd. both interacting externally along the supply chain (e.g. the customers and other companies involved in waste management processes) and internally, managing its operations.

As a whole, the diagram allows identifying the four feedback loops we portrayed in Figure 3 since the company acquires raw materials and wasteful items outside of the company thereby recycling waste (loop R4-recycling) and subsequently (re)manufacturing them (loop R3-remanufacturing) to generate new products for the customers. At the same time, the company operates through the other two loops since it generates packaging that is suitable to be reused multiple times (thereby favoring loop R1-reusing) and that could be even repaired (loop R2-repairing). Considered together and holistically, these four exercises are integrated into a closed-loop system for the whole business domain, thereby generating value for - and with the co-operation of - all the players along the supply chain. Paper Mill 
IJPPM

70,8

\section{4}

Figure 4 .

Subsystem diagram for Paper Mill Ltd.'s business environment (operations with a focus on $\mathrm{CE}$ )

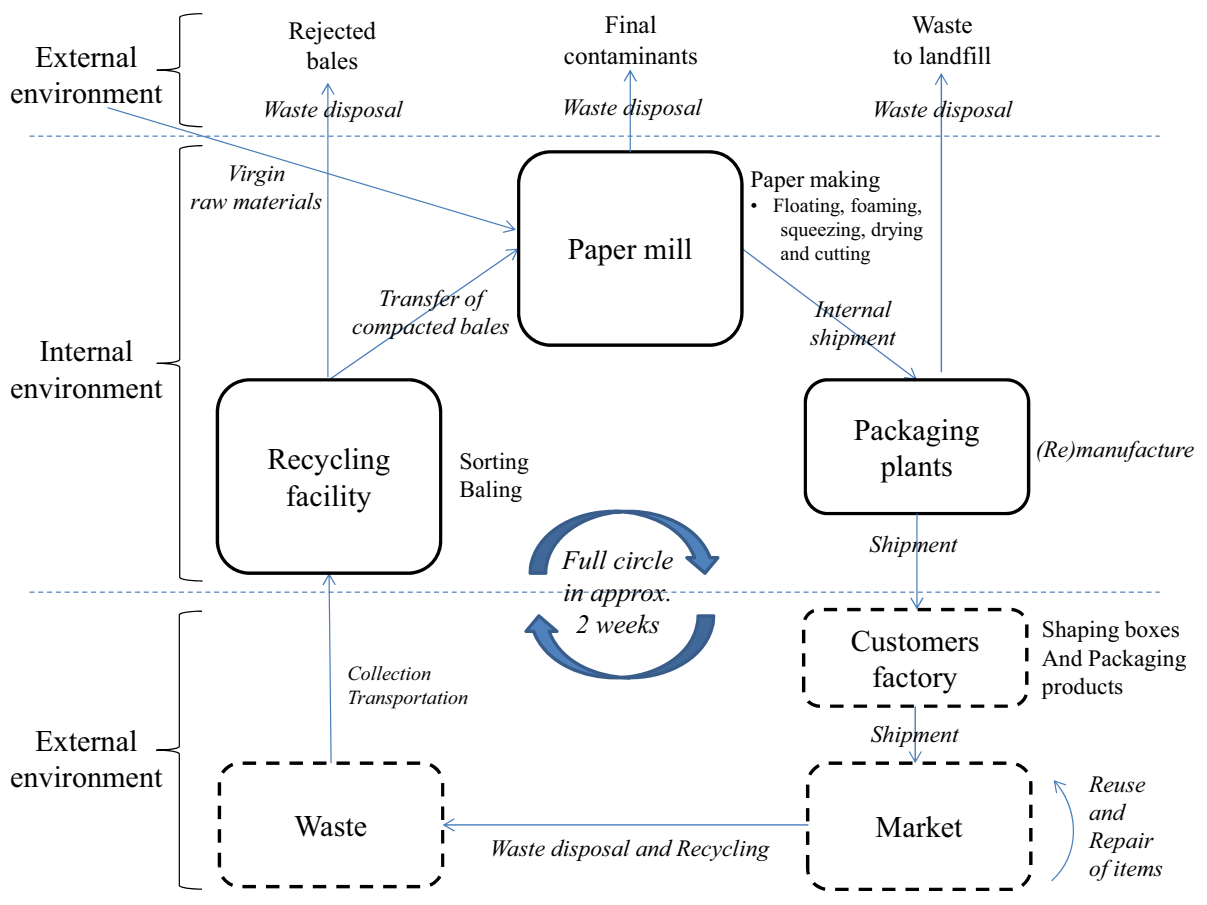

Ltd. can close an entire cycle of recycling in approximately two weeks, given how the business domain is structured.

The processes aforementioned pursue the ultimate goal of providing cost-effective, efficient, innovative and sustainable services and products for Paper Mill's customers, at the same time generating value from waste for the whole society.

As stated by the manager of the branch, "we play a relevant role in the society since we transform what people consider waste into something new, i.e. into products which have a value for us and our customers".

The key operations summarized by the subsystem diagram depicted in Figure 4 represent how this business domain is structured around CE activities and concepts. Starting from this basis, we addressed more specifically how IR principles and concepts may help to analyze further such processes and information. Subsequently, a second subsystem diagram (Figure 5) was developed to portray explicitly the typologies of capitals used by Paper Mill Ltd. We remind that, according to IIRC (2013a), capitals are divided into six typologies useful to emphasize their different nature and role (see the legend in Figure 5).

This subsystem diagram shows that all the capitals identified by the IIRC framework (IIRC, 2013a) play a role along the supply chain and about the operations and stages of the recycling process. The figure also reveals that several capitals need to contribute simultaneously to sustain specific phases, areas or processes along this supply chain and business domain.

As stated by the chief engineer we met during the visit to the company's branch,

Paper Mill Ltd. relies on different resources: we need financial capital to invest and make transactions; we need people since operators are a relevant part of the process; we definitely need 


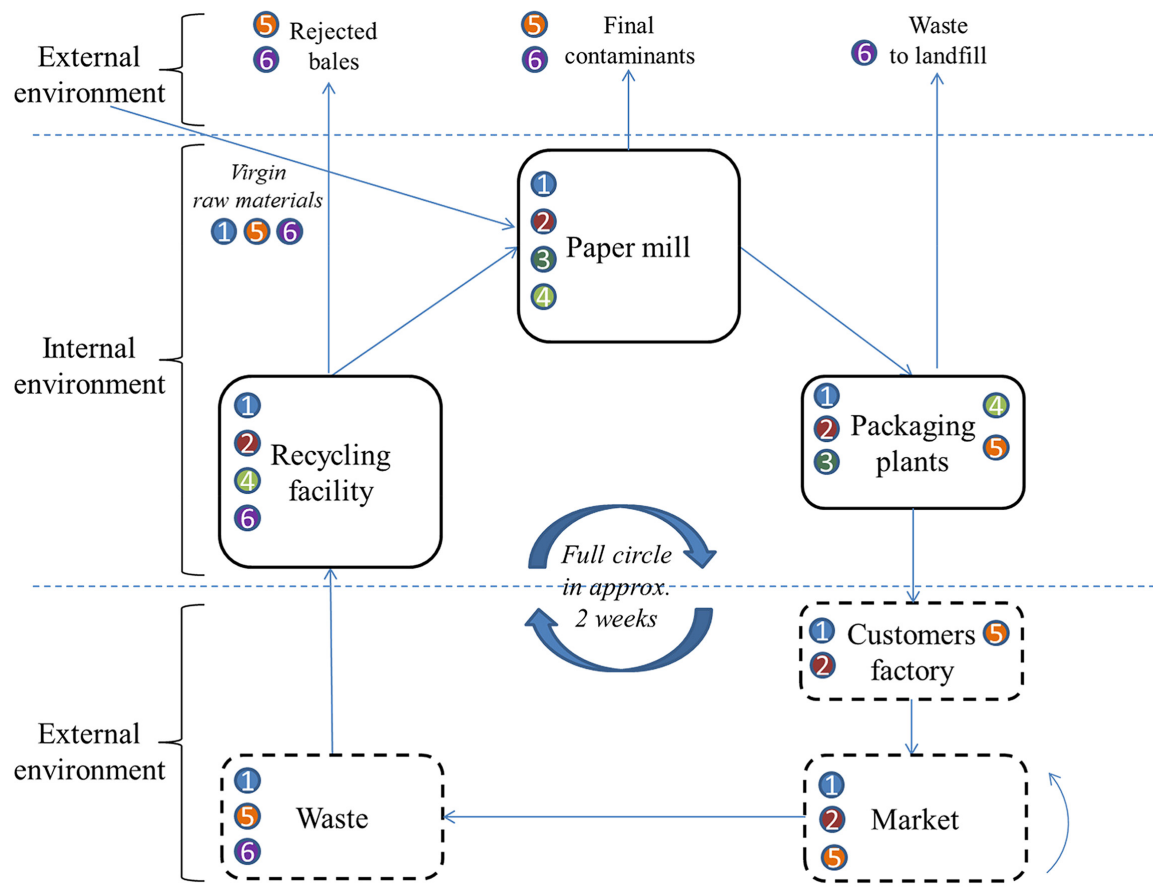

Legend: (1) Financial; 2 Manufactured; (3) Intellectual; (9) Human; (5) Social and Relationship; 6 Natural
Integrated reporting and circular economy

2015
Figure 5. Subsystem diagram for Paper Mill Ltd.'s business environment (focus on IR)

machinery and updated technology; and we need relationships since we trade with our clients, but we also need to influence people to recycle and provide what we need at first, the raw materials.

Otherwise, we cannot produce.

This statement emphasizes not only the existence and use of the various capitals theorized by the IR Framework but also that such capitals are intertwined and dependent one upon the other, therefore reinforcing the idea of integration and holistic representation that both IR and CE convey.

An additional step of the case study entailed spotting outputs and outcomes stemming from the operations carried out by the company.

Considering that the reports of this organization disclose indicators and measures in financial, environmental and social terms, in this section of the paper a specific emphasis is given to the connections existing among them. Specifically, using a triangulation of the data at disposal (Patton, 1987), we developed a causal diagram (Figure 6) portraying a chain of cause-and-effect relationships for Paper Mill Ltd.

Using causal connections similarly to what is done in causal mapping (e.g. Eden et al., 1992), this diagram clarifies how inputs (e.g. financial, human, natural and manufactured capitals) are transformed through business activities (e.g. designing new products and manufacturing the raw materials) into an array of outputs (e.g. the products being customized for the company's clients) and outcomes. This is in line with the IR framework and its core elements (IIRC, 2013a). Additionally, the diagram allows explaining that the decisions and actions of Paper Mill Ltd. impact on several factors, both internally (e.g. less warehouse space 


\section{IJPPM}

70,8

\section{6}

Figure 6.

Causal diagram for

Paper Mill Ltd.

showing actions,

outputs and outcomes

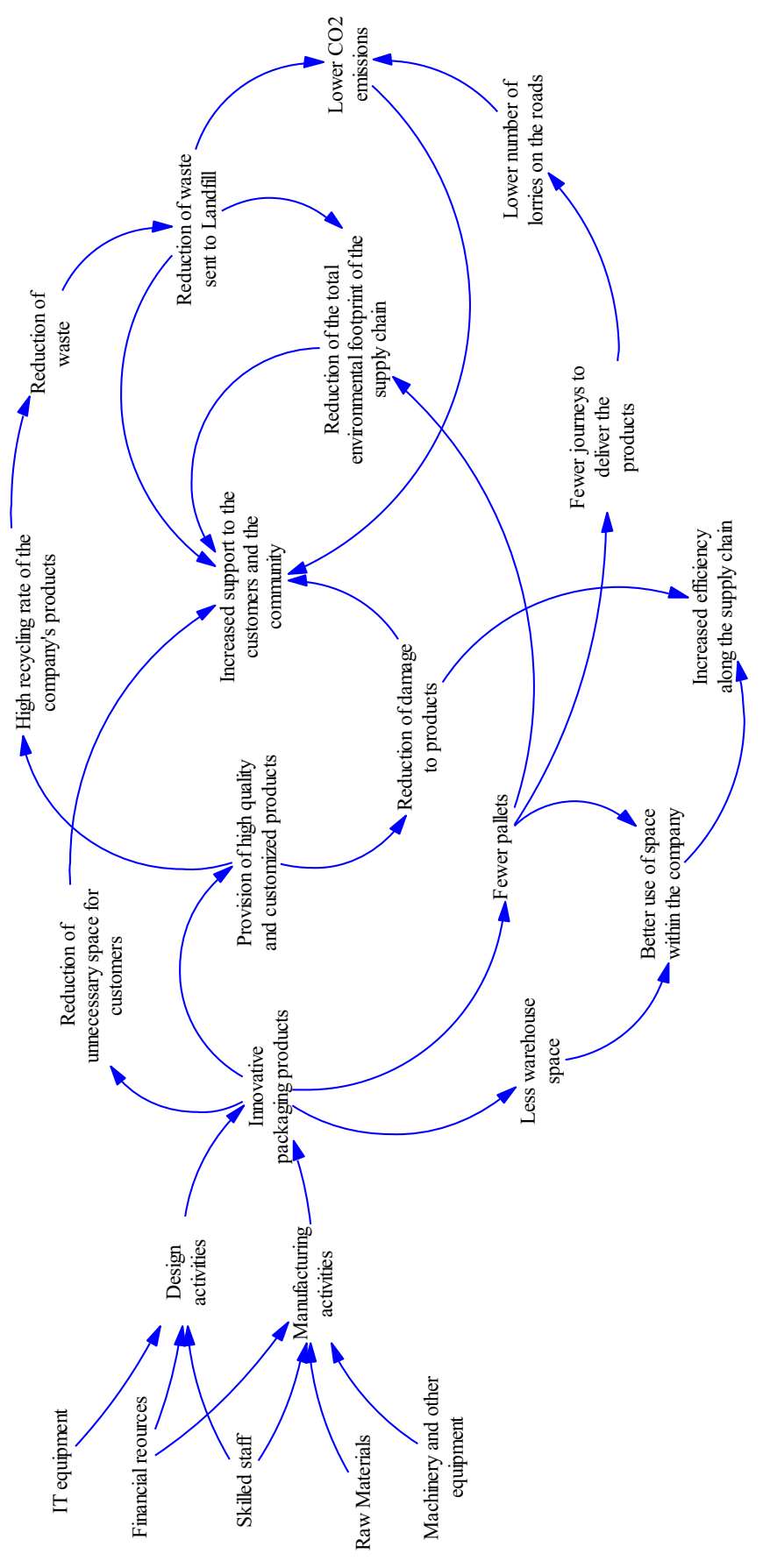


needed) and externally (e.g. a diminution in products being damaged). Last, this map allows identifying several outcomes characterizing this business domain, including environmental consequences of the operations (e.g. reduced $\mathrm{CO} 2$ emissions deriving from a lower number of lorries used to ship the products), economic benefits (e.g. an overall increase in efficiency along the supply chain that will generate profitability) and social gains (e.g. enhanced support to the community).

\section{Discussion and conclusion}

Addressing the calls from the academia and the business world that encourage and recommend more research on $\mathrm{CE}$ and the disclosure of CE-related information (e.g. KampRoelands, 2013; EEA, 2016; Deloitte, 2017; Stewart and Niero, 2018; Dewick et al., 2020; Kunc et al., 2020a), this study aimed at discussing the role that might be played in this context by the principles and the content elements provided by the integrated reporting framework (IIRC, 2013a).

IR (alongside other sustainability and environmental reports) offers a potentially powerful tool that organizations all over the world could use to analyze and disclose their CE initiatives, the performance and the results subsequently achieved and the main impacts thereby generated. Specifically, this study explored the primary nexus of IR with CE, at first from a theoretical point of view and, subsequently, performing textual content analysis and presenting a case study.

The first aim of the article entailed discussing how the IR framework may support the (re) presentation of CE-related activities and information, thereby addressing a research gap in the literature (e.g. Stewart and Niero, 2018 and Kunc et al., 2020a). As discussed in Section 2, $\mathrm{CE}$ and IR share several underlying concepts and are based on and entail the presence and action of closed-loop exercises among a bundle of intertwined resources and processes. With this said, whereas previous literature extensively discussed the features, potentials and strengths of IR or CE, also in terms of reporting practices (e.g. Eccles and Krzus, 2011; Adams, 2015; Dumay et al., 2016; Geissdoerfer et al., 2017; Korhonen et al., 2018b), the joint use of IR and $\mathrm{CE}$ is still under-researched, thereby calling for more investigation (e.g. Kamp-Roelands, 2013; Stewart and Niero, 2018; Kunc et al., 2020a). Subsequently, the second aim of the paper was to explore how and to what extent current IR practices are including and disclosing CErelated information.

The content analysis (Krippendorf, 2004) we performed allowed identifying 1.611 .522 terms of interest for this study (given the codebook defined ex ante and searched for with the software N-Vivo 12 Pro). Those terms were reclassified into the four categories of elements theorized by the IIRC (2013a), i.e. inputs, business activities, outputs and outcomes. We believe that such reclassification is useful not only to organize and make clear the results but also to make underlying information come on the surface about how organizations include and disclose CE-related data. Stated differently, having created four "categories" for the 98 concepts we looked for allows speculating on actual CE reporting practices and may offer support for providing suggestions on organizing the content of such communication in the future. Particularly, this reclassification entails focusing more on groups of concepts rather than on single terms, thereby primarily emphasizing a more general reporting approach to $\mathrm{CE}$ (in this case, the IR Framework) rather than spotting the most-cited terms in the reports. This is in line with the studies that suggest using content analysis to create new knowledge in terms of categories and groups of concepts, rather than in terms of single concepts and their counts (e.g. Guthrie et al., 2004). Last, our proposition is also in line with part of the academic debate (e.g. see Busco et al., 2018 and Rodríguez-Gutiérrez et al., 2019) that looks at IR as a tool able to transform itself to adapt to the peculiarities and the institutional and managerial factors characterizing the organizations interested in reporting sustainability data with an
Integrated
reporting and
circular
economy

2017 
IJPPM 70,8 integrated report, thereby going beyond the boundaries of specific industries or geographical areas.

The third aim of this study entailed developing an exploratory case study (Ryan et al., 2002) with an action research perspective (Lewin, 1946). The results from the case study witness how relevant $\mathrm{CE}$ can be in specific operational domains and, more importantly, in closed-loop supply chains where the cooperation and interaction of multiple players are fundamental to create value from waste (e.g. Tajbakhsh and Hassini, 2015; Kazemi et al., 2019) and with a holistic perspective. Particularly, the case study emphasized not only that modern companies can run their operations focusing on and exploiting $\mathrm{CE}$ - thereby reducing waste and favoring the exercises of reusing and repairing their products - but also that they are keen on cooperating with other players along the supply chain to increase efficiency and profitability for all of them. Stated differently, this approach is suitable to provide benefits, when applied properly, at different levels (see Kirchherr et al., 2017; Werning and Spinler, 2020), such as the micro- (e.g. products, companies, and consumers), meso- (e.g. eco-industrial parks) and macro-level (e.g. city, region, nation, and beyond).

Specifically, the results of the case study emphasize how an integrated, comprehensive and holistic view - such as the one conveyed through IR lenses - is useful to analyze and manage business domains which are characterized by multiple agents interacting together.

As the manager at the branch underlined:

Definitely, we need an integrated approach to run our business. Look, we are not alone out there and we cannot do everything by ourselves. As an example, to generate the new packaging products that we sell to our customers, we need the cardboard to be free from any other material, such as food or plastics. It has to be of a high or good quality. (...)

Each player has to do something, with a purpose. As a simple example, consider that to get cardboard as our raw material, we need the end-users not to throw away their waste, rather be the ones that start the recycling process.

In these terms, we particularly underlined how IR concepts fit well with $\mathrm{CE}$ and also that the principle of "integrated thinking" may effectively support organizations to identify, manage and exploit all the interrelationships among units, resources and functions within their business domains (IIRC, 2013a; Busco et al., 2017; Kunc et al., 2020b). In this regard, we stress again that the concept of closed loop that we recalled and used in this study is fundamental in order to make possible the transition from a linear-oriented to an integrated and circularbased model (Golroudbary and Zahraee, 2015). When this happens, organizations will no more rely only on separate sets of inputs, activities, outputs and outcomes but on a web of feedback processes able to connect continuously and in a widespread manner such elements.

As the chief engineer of the company underlined,

you can actually see the CE here. (emphasis added)

Through the development of two different subsystem diagrams (Sterman, 2000) and one causal diagram (Eden et al., 1992), and according to an action research approach to the case study, we highlighted how the four categories of IR concepts (inputs, business activities, outputs, and outcomes) come into play in this domain.

Specifically, the potentials of using IR and CE together are confirmed by Figure 5 of this study, that helped to summarize how the various typologies of capitals theorized by the IR framework (2013a) are exploited jointly to run a fully integrated and CE-oriented business environment. Notably, all of the capitals theorized by IIRC (2013a) are shown and play a role in organizing and carrying out the company's business activities.

Various outputs and outcomes are represented as well, not only by Figure 5 but also by Figure 6 that, more specifically, shows that the outputs and outcomes of the company's 
business operations include environmental impacts as well as social consequences. Particularly, the relevance of the intellectual capital and the social and relationship capital as starting points of the company's value creation process, and the achievement of sociallyrelated outcomes of its operations are emphasized in all the reports drawn up by Paper Mill Ltd. and were also underlined by the manager we interviewed.

We innovate, continuously. And we build relationships. First, we innovate, renewing and improving our products and technologies to provide a more customized service to our clients. Second, we build a ton of relationships, with the other players along the supply chain, and with our community. We try to influence people, and let them understand that recycling is relevant, and matters. In the end, we try to give back to the community.

This is particularly interesting, from our perspective: identifying, managing and exploiting all the four loops provided within a CE-based framework allows Paper Mill Ltd. generating sustainable value (see Nouri et al., 2019b) for - and with the co-operation of - all the players along its supply chain.

In conclusion, we believe that this work is of interest for both academics and practitioners since it represents one of the first studies which not only advocates to embed CE information and measures into sustainability and corporate reports but also carries out an exploratory analysis investigating if the practice provides any evidence, in this case focusing on IR. We also believe that this study might be of interest to regulators, suggesting an increased role of IR practices to ensure the disclosure of CE-related information in a well-organized, comparable and comprehensive way. Notably, it is authors' opinion that the interplays between IR and $\mathrm{CE}$ can provide a range of benefits for the organizations and the actors operating in such domains at different levels (e.g. a single company or companies cooperating within a supply chain as well as big organizations or small and medium-size companies), in different industries (e.g. in the manufacturing or the service industry) or geographical areas, as somehow suggested by previous research (e.g. Rodríguez-Gutierrez et al., 2019; Nouri et al., 2019b; Kunc et al., 2020a; Dey et al., 2020). In the end, the core elements (e.g. the set of capitals theorized by IIRC, 2013a), the key principles (e.g. the principles of connectivity and integrated thinking) and the fundamental processes (the $4 \mathrm{R}$ exercises of reusing, repairing, remanufacturing and recycling) can be effectively applied in any business context.

Last, our study may aid in the development and diffusion of a more standardized and established terminology for CE-related research and reporting practices, something that is currently missing.

\section{Limitations and further research}

Our study is not without limitations.

One limitation may be linked to the dataset used to perform content analysis. Our choice was to rely on the official website of the IIRC, and specifically, on "The Integrated Reporting Examples Database". Although this database has been considered a reliable and relevant source of information (e.g. Dumay et al., 2017; Zhou et al., 2017), other IR practices may exist worldwide outside of its boundary. However, retrieving the documents from one single source allowed consistency among the reports included in the study.

Second, the glossary used for this research is derived from the US Chamber of Commerce. This choice is justified by the lack of a standardized glossary of CE-related terms at the global level (Korhonen et al., 2018b). To mitigate a potential bias in how this glossary was formed, we used some additional terms (selected applying a brainstorming method-Wilson, 2013) as well as synonyms (created by the N-Vivo 12 Pro software). As mentioned, overall this study may contribute to the diffusion of a more standardized and established terminology for CE-related research and reporting practices.
Integrated
reporting and
circular
economy

2019 
IJPPM 70,8
Last, from a methodological point of view, we are aware of the fact that content analysis primarily provides information about the quantity of the concepts being searched and not about the quality of such information (Guthrie and Abeysekera, 2006) or about how the concepts relate to each other within an organization's CE strategies. This is why our research design entailed grouping the concepts according to the key categories of elements as provided by IIRC (2013a) and subsequently used such categories to develop an exploratory case study (Ryan et al., 2002) with an action research perspective (Lewin, 1946).

However, we believe that the limitations aforementioned also open up avenues for further research and specifically toward the development of additional qualitative case studies (Yin, 1994; Ryan et al., 2002) in an attempt to uncover further and explain the reasons for observed CE-related reporting practices and understand to what extent IR may stimulate new disclosure mechanism (Stubbs and Higgins, 2014 about this) as well as more structured interaction with the organization's stakeholders (Jakkar et al., 2019). Additionally, further research will be also oriented toward the investigation and discussion of how the interplays between $\mathrm{CE}$ and IR practices might take place differently in various industries (e.g. in the manufacturing industry vs the service industry, e.g. Garza-Reyes et al., 2019a and b, and Nouri et al., 2019b) or focusing on planning and production processes at the micro-. meso- or macro-level (Kirchherr et al., 2017) with the ultimate aim to accomplish sustainable development and measure it (Garza-Reyes et al., 2019a; Corona et al., 2019).

With a different aim, statistical analyses could be performed to correlate data emerging from the content analysis with a range of other factors considered to be relevant for CE (e.g. capitals, or specific KPIs and CE-related metrics) thereby addressing the calls for more investigation about the determinants and the indicators of CE-related activities (e.g. Ellen MacArthur Foundation, 2015a; Moraga et al., 2019; Kristensen and Mosgaard, 2020).

\section{Note}

1. In this article we refer to a framework for CE based on " $4 \mathrm{R}$ " exercises: Reusing, Repairing, Remanufacturing, and Recycling. Other studies have expanded such framework to include other exercises, such as the "6R's approach" (e.g. Govindan and Hasanagic, 2018) that adds the concepts of Recovering and Redesigning, or even 9R's, 10R's or 11R's approaches (see Reike et al., 2018 for a review).

\section{References}

Abeysekera, I. (2013), “A template for integrated reporting”, Journal of Intellectual Capital, Vol. 14 No. 2, pp. 227-245.

Abuabara, L., Paucar-Caceres, A. and Burrowes-Cromwell, T. (2019), "Consumers' values and behaviour in the Brazilian coffee-in-capsules market: promoting circular economy", International Journal of Production Research, Vol. 57 No. 23, pp. 7269-7288.

Adams, C.A. (2015), "The international integrated reporting Council: a call to action", Critical Perspectives on Accounting, Vol. 27 No. 1, pp. 23-28.

Adams, C. (2017), Understanding Integrated Reporting: The Concise Guide to Integrated Thinking and the Future of Corporate Reporting, Routledge, London.

Andersen, M.S. (2007), "An introductory note on the environmental economics of the circular economy”, Sustainability Science, Vol. 2 No. 1, pp. 133-140.

Atkins, J., Atkins, B.C., Thomson, I. and Maroun, W. (2015a), ““Good” news from nowhere: imagining utopian sustainable accounting", Accounting, Auditing and Accountability Journal, Vol. 28 No. 5 , pp. $651-670$.

Atkins, J.F., Solomon, A., Norton, S. and Joseph, N.L. (2015b), "The emergence of integrated private reporting”, Meditari Accountancy Research, Vol. 23 No. 1, pp. 28-61. 
Baret, P. and Helfrich, V. (2019), "The 'trilemma' of non-financial reporting and its pitfalls”, Journal of Management and Governance, Vol. 23 No. 2, pp. 485-511.

Barnabè, F., Giorgino, M.C. and Kunc, M. (2019), "Visualizing and managing value creation through integrated reporting practices: a dynamic resource-based perspective”, Journal of Management and Governance, Vol. 23 No. 2, pp. 537-575.

Beattie, V. and Smith, S.J. (2013), "Value creation and business models: refocusing the intellectual capital debate”, The British Accounting Review, Vol. 45 No. 4, pp. 243-254.

Berelson, B. (1952), Content Analysis in Communication Research, Free Press, New York, NY.

Bourguignon, D. (2016), “Closing the loop: new circular economy package”, European Parliamentary Research Service, No. 9, pp. 1-9.

Busco, C., Frigo, M.L., Riccaboni, A. and Quattrone, P. (Eds) (2013), Integrated Reporting. Concepts and Cases that Redefine Corporate Accountability, Springer, Switzerland.

Busco, C., Granà, F. and Quattrone, P. (2017), "Integrated thinking: aligning purpose and the business model to market opportunities and sustainable", Association of International Certified Professional Accountants, CIMA Research Executive Summary, Vol. 13 No. 3, pp. 1-26.

Busco, C., Giovannoni, E., Granà, F. and Izzo, M.F. (2018), "Making sustainability meaningful: aspirations, discourses and reporting practices", Accounting, Auditing and Accountability Journal, Vol. 31 No. 8, pp. 2218-2246.

Corona, B., Shen, L., Reike, D., Carreón, J.R. and Worrell, E. (2019), "Towards sustainable development through the circular economy-A review and critical assessment on current circularity metrics", Resources, Conservation and Recycling, Vol. 151, 104498.

De Sousa Jabbour, A.B.L., Luiz, J.V.R., Luiz, O.R., Jabbour, C.J.C., Ndubisi, N.O., De Oliveira, J.H.C. and Junior, F.H. (2019), "Circular economy business models and operations management", Journal of Cleaner Production, Vol. 235, pp. 1525-1539.

De Villiers, C. and Sharma, U. (2020), "A critical reflection on the future of financial, intellectual capital, sustainability and integrated reporting", Critical Perspectives on Accounting, Vol. 70, 101999.

Deloitte (2017), Transform Your Business, Deloitte Sustainability Consulting, Central Europe.

DeLorenzo, A., Parizeau, K. and Von Massow, M. (2019), "Regulating Ontario's circular economy through food waste legislation”, Society and Business Review, Vol. 14 No. 2, pp. 200-216.

Dewick, P., Bengtsson, M., Cohen, M.J., Sarkis, J. and Schröder, P. (2020), "Circular economy finance: clear winner or risky proposition?”, Journal of Industrial Ecology. doi: 10.1111/jiec.13025.

Dey, P.K., Malesios, C., De, D., Budhwar, P., Chowdhury, S. and Cheffi, W. (2020), "Circular economy to enhance sustainability of small and medium-sized enterprises", Business Strategy and the Environment, Vol. 29 No. 6, pp. 2145-2169.

Di Vaio, A., Syriopoulos, T., Alvino, F. and Palladino, R. (2020), "Integrated thinking and reporting' towards sustainable business models: a concise bibliometric analysis", Meditari Accountancy Research. doi: 10.1108/MEDAR-12-2019-0641.

Dresch, A., Lacerda, D.P. and Miguel, P.A.C. (2015), “A distinctive analysis of case study, action research and design science research", Review of Business Management, Vol. 17 No. 56, pp. 1116-1133.

Druckman, P. (2017), "Foreword", in Adams, C. (Ed.), Understanding Integrated Reporting: The Concise Guide to Integrated Thinking and the Future of Corporate Reporting, Routledge, NY, pp. 23-25.

Dumay, J., Bernardi, C., Guthrie, J. and Demartini, P. (2016), "Integrated reporting: a structured literature review", Accounting Forum, Vol. 40 No. 3, pp. 166-185.

Dumay, J., Bernardi, C., Guthrie, J. and La Torre, M. (2017), "Barriers to implementing the international integrated reporting framework: a contemporary academic perspective", Meditari Accountancy Research, Vol. 25 No. 4, pp. 461-480.

EC-European Commission (2014a), Towards a Circular Economy: A Zero Waste Programme for Europe, European Commission, Brussels.
Integrated reporting and circular economy 
IJPPM 70,8

EC-European Commission (2014b), Scoping Study to Identify Potential Circular Economy Actions, Priority Sectors, Material Flows, and Value Chains, European Commission, Brussels.

Eccles, R.G. and Krzus, M.P. (2011), One Report: Integrated Reporting for a Sustainable Strategy, John Wiley and Sons, New York, NY.

Eccles, R.G. and Saltzman, D. (2011), "Achieving sustainability through integrated reporting", Stanford Social Innovation Review, Summer, Vol. 59, pp. 56-61.

Eden, C., Ackermann, F. and Cropper, S. (1992), "The analysis of cause maps", Journal of Management Studies, Vol. 29 No. 3, pp. 309-324.

EEA - European Environment Agency (2016), Circular Economy in Europe: Developing the Knowledge Base, Publications Office of the European Union, Luxembourg, No. 2/2016.

Elia, V., Gnoni, M.G. and Tornese, F. (2017), "Measuring circular economy strategies through index methods: a critical analysis", Journal of Cleaner Production, Vol. 142, pp. 2741-2751.

Eisenhardt, K.M. (1989), "Building theories from case study research", Academy of Management Review, Vol. 14 No. 4, pp. 532-550.

Ellen MacArthur Foundation (2013), "Towards the circular economy", Economic and Business Rationale for an Academic Transition, Vol. 1.

Ellen MacArthur Foundation (2014), "Towards the circular economy”, Accelerating the Scale-up Across Global Supply Chains, Vol. 3.

Ellen MacArthur Foundation (2015a), "Circularity indicators. an approach to measuring circularity", Project Overview, May 2015.

Ellen MacArthur Foundation (2015b), Delivering the Circular Economy. A Toolkit for Policymakers, available at: https://www.ellenmacarthurfoundation.org/assets/downloads/publications/Ellen MacArthurFoundation_PolicymakerToolkit.pdf.

Flynn, A. and Hacking, N. (2019), "Setting standards for a circular economy: a challenge too far for neoliberal environmental governance?", Journal of Cleaner Production, Vol. 212, pp. 1256-1267.

Garza-Reyes, J.A., Valls, A.S., Nadeem, S.P., Anosike, A. and Kumar, V. (2019a), "A circularity measurement toolkit for manufacturing SMEs", International Journal of Production Research, Vol. 57 No. 23, pp. 7319-7343.

Garza-Reyes, J., Kumar, V., Batista, L., Cherrafi, A. and Rocha-Lona, L. (2019b), "From linear to circular manufacturing business models", Journal of Manufacturing Technology Management, Vol. 30 No. 3, pp. 554-560.

Geissdoerfer, M., Savaget, P., Bocken, N.M. and Hultink, E.J. (2017), "The circular economy-a new sustainability paradigm?”, Journal of Cleaner Production, Vol. 143, pp. 757-768.

Geng, Y., Fu, J., Sarkis, J. and Xue, B. (2012), "Towards a national circular economy indicator system in China: an evaluation and critical analysis", Journal of Cleaner Production, Vol. 23 No. 1, pp. 216-224.

Giorgino, M.C., Barnabè, F. and Paolicelli, N. (2016), "Searching for the missing link between business model and strategy: the Integrated Reporting perspective", in Jablonski, A. (Ed.), Business Models: Strategies, Impact, and Challenges, Nova Science Publisher, New York, NY, Chapter 6, pp. 101-133.

Giorgino, M.C., Barnabè, F. and Kunc, M. (2019), "Integrating qualitative system dynamics with accounting practices: the case of integrated reporting and resource mapping", Systems Research and Behavioral Science, Vol. 37 No. 1, pp. 97-118.

Golroudbary, S.R. and Zahraee, S.M. (2015), "System dynamics model for optimizing the recycling and collection of waste material in a closed-loop supply chain", Simulation Modelling Practice and Theory, Vol. 53, pp. 88-102.

Govindan, K. and Hasanagic, M. (2018), "A systematic review on drivers, barriers, and practices towards circular economy: a supply chain perspective", International Journal of Production Research, Vol. 56 Nos 1-2, pp. 278-311. 
Guthrie, J. and Abeysekera, I. (2006), "Content analysis of social, environmental reporting: what is new?", Journal of Human Resource Costing and Accounting, Vol. 10 No. 2, pp. 114-126.

Guthrie, J., Petty, R., Yongvanich, K. and Ricceri, F. (2004), "Using content analysis as a research method to inquire into intellectual capital reporting", Journal of Intellectual Capital, Vol. 5 No. 2, pp. 282-293.

Guthrie, J., Manes-Rossi, F. and Orelli, R.L. (2017), "Integrated reporting and integrated thinking in Italian public sector organisations", Meditari Accountancy Research, Vol. 25 No. 4, pp. 553-573.

Ieng Chu, C., Chatterjee, B. and Brown, A. (2012), "The current status of greenhouse gas reporting by Chinese companies: a test of legitimacy theory”, Managerial Auditing Journal, Vol. 28 No. 2, pp. 114-139.

International Integrated Reporting Council (IIRC) (2013a), The International $<I R>$ Framework, available at: http://www.theiirc.org/international-ir-framework/.

International Integrated Reporting Council (IIRC) (2013b), Business Model. Background Paper for $<I R>$, available at: https://integratedreporting.org/wp-content/uploads/2013/03/Business_ Model.pdf.

International Integrated Reporting Council (IIRC) (2013c), Value Creation. Background Paper for $<I R>$, available at: http://integratedreporting.org/wp-content/uploads/2013/08/BackgroundPaper-Value-Creation.pdf.

International Integrated Reporting Council (IIRC) (2013d), Capitals. Background Paper for $\langle I R>$, available at: http://integratedreporting.org/wp-content/uploads/2013/03/IR-Background-PaperCapitals.pdf.

International Integrated Reporting Council (IIRC) (2016), Creating Value the Cyclical Power of Integrated Thinking and Reporting, available at: https:/integratedreporting.org/wp-content/ uploads/2017/05/CreatingValue_IntegratedThinkingK1.pdf.

Jakhar, S.K., Mangla, S.K., Luthra, S. and Kusi-Sarpong, S. (2019), "When stakeholder pressure drives the circular economy. Measuring the mediating role of innovation capabilities", Management Decision, Vol. 57 No. 4, pp. 904-920.

Kamp-Roelands, N. (2013), "A commentary on 'integrated reporting: a review of developments and their implications for the accounting curriculum", Accounting Education, Vol. 22 No. 4, pp. 357-359.

Kazemi, N., Modak, N.M. and Govindan, K. (2019), "A review of reverse logistics and closed loop supply chain management studies published in IJPR: a bibliometric and content analysis", International Journal of Production Research, Vol. 57 Nos 15-16, pp. 4937-4960.

Kirchherr, J., Reike, D. and Hekkert, M. (2017), “Conceptualizing the circular economy: an analysis of 114 definitions. Resources", Conservation and Recycling, Vol. 127, pp. 221-232.

Korhonen, J., Nuur, C., Feldmann, A. and Birkie, S.E. (2018a), "Circular economy as an essentially contested concept”, Journal of Cleaner Production, Vol. 175, pp. 544-552.

Korhonen, J., Honkasalo, A. and Seppälä, J. (2018b), "Circular economy: the concept and its limitations”, Ecological Economics, Vol. 143, pp. 37-46.

Kozlowski, A., Searcy, C. and Bardecki, M. (2015), "Corporate sustainability reporting in the apparel industry an analysis of indicators disclosed", International Journal of Productivity and Performance Management, Vol. 64 No. 3, pp. 377-397.

Kraaijenhagen, C., Van Oppen, C. and Bocken, N. (2016), Circular Business, Collaborate and Circulate, Circular Collaboration, Amersfoort.

Krippendorff, K. (2004), Content Analysis: An Introduction to its Methodology, SAGE Publications, Thousand Oaks, CA.

Kristensen, H.S. and Mosgaard, M.A. (2020), "A review of micro level indicators for a circular economy-moving away from the three dimensions of sustainability?", Journal of Cleaner Production, Vol. 243, 118531.
Integrated reporting and circular economy 
IJPPM 70,8

Kunc, M.H., Barnabè, F. and Giorgino, M.C. (2020a), "Mapping circular economy processes in integrated reporting: a dynamic resource-based approach”, in Songini, L., Pistoni, A., Baret, P. and Kunc, M.H. (Eds), Non-financial Disclosure and Integrated Reporting. Practices and Critical Issues, Book Series: Studies in Managerial and Financial Accounting (SMFA), Emerald Publishing, Vol. 34, Bingley, pp. 83-106.

Kunc, M.H., Giorgino, M.C. and Barnabè, F. (2020b), Developing Forward-Looking Orientation in Integrated Reporting, Meditari Accuntancy Research. doi: 10.1108/MEDAR-12-2019-0664.

Lewin, K. (1946), “Action research and minority problems", Journal of Social Issues, Vol. 2 No. 4, pp. 34-46.

Lüdeke-Freund, F., Gold, S. and Bocken, N.M. (2019), "A review and typology of circular economy business model patterns", Journal of Industrial Ecology, Vol. 23 No. 1, pp. 36-61.

McDowall, W., Geng, Y., Huang, B., Barteková, E., Bleischwitz, R., Türkeli, S., Kemp, R. and Doménech, T. (2017), "Circular economy policies in China and Europe", Journal of Industrial Ecology, Vol. 21 No. 3, pp. 651-661.

McNally, M.A., Cerbone, D. and Maroun, W. (2017), "Exploring the challenges of preparing an integrated report", Meditari Accountancy Research, Vol. 25 No. 4, pp. 481-504.

Mihelcic, J.R., Crittenden, J.C., Small, M.J., Shonnard, S.D.R., Hokanson, D.R., Zhang, Q., Chen, H., Sorby, S.A., James, V.U., Sutherland, J.W. and Schnoor, J.L. (2003), "Sustainability science and engineering: the emergence of a new metadiscipline", Environmental Science and Technology, Vol. 37 No. 23, pp. 5314-5324.

Millar, N., McLaughlin, E. and Börger, T. (2019), "The circular economy: swings and roundabouts?", Ecological Economics, Vol. 158, pp. 11-19.

Moraga, G., Huysveld, S., Mathieux, F., Blengini, G.A., Alaerts, L., Van Acker, K., De Meester, S. and Dewulf, J. (2019), "Circular economy indicators: what do they measure?", Resources, Conservation and Recycling, Vol. 146, pp. 452-461.

Murray, A., Skene, K. and Haynes, K. (2017), "The circular economy: an interdisciplinary exploration of the concept and application in a global context", Journal of Business Ethics, Vol. 140 No. 3, pp. 369-380.

Neuendorf, K. (2002), The Content Analysis Guidebook, Sage, Thousand Oaks, CA.

Nouri, F.A., Nikabadi, M.S. and Olfat, L. (2019a), "Developing the framework of sustainable service supply chain balanced scorecard (SSSC BSC)", International Journal of Productivity and Performance Management, Vol. 68 No. 1, pp. 148-170.

Nouri, F.A., Nikabadi, M.S. and Olfat, L. (2019b), "Sustainable service supply chain practices (SSSCPs): a framework development", International Journal of Productivity and Performance Management, Vol. 69 No. 4, pp. 813-833.

Park, J., Sarkis, J. and Wu, Z. (2010), "Creating integrated business and environmental value within the context of China's circular economy and ecological modernization", Journal of Cleaner Production, Vol. 18 No. 15, pp. 1494-1501.

Patton, M.Q. (1987), How to Use Qualitative Methods in Evaluation, Sage, Beverly Hills.

Pistoni, A., Songini, L. and Bavagnoli, F. (2018), "Integrated reporting quality: an empirical analysis", Corporate Social Responsibility and Environmental Management, Vol. 25 No. 4, pp. 489-507.

Reason, P. and Bradbury, H. (Eds) (2001), Handbook of Action Research: Participative Inquiry and Practice, Sage Publications, London.

Reike, D., Vermeulen, W.J. and Witjes, S. (2018), "The circular economy: new or refurbished as CE 3.0? Exploring controversies in the conceptualization of the circular economy through a focus on history and resource value retention options", Resources, Conservation and Recycling, Vol. 135, pp. 246-264.

Richardson, G.P. (1999), Feedback Thought in Social Science and Systems Theory, Pegasus Communications, Waltham. 
Rodríguez-Gutiérrez, P., Correa, C. and Larrinaga, C. (2019), "Is integrated reporting transformative? An exploratory study of non-financial reporting archetypes", Sustainability Accounting, Management and Policy Journal, Vol. 10 No. 3, pp. 617-644.

Ryan, B., Scapens, R.W. and Theobald, M. (2002), Research Method and Methodology in Finance and Accounting, 2nd ed., Thomson, London.

Scapens, R.W. (1990), "Researching management accounting practice: the role of case study research methods", British Accounting Review, Vol. 22 No. 3, pp. 259-281.

Schilling, J. (2006), "On the pragmatics of qualitative assessment: designing the process for content analysis", European Journal of Psychological Assessment, Vol. 22 No. 1, pp. 28-37.

Stacchezzini, R., Melloni, G. and Lai, A. (2016), "Sustainability management and reporting: the role of integrated reporting for communicating corporate sustainability management”, Journal of Cleaner Production, Vol. 136, pp. 102-110.

Stahel, W.R. (1982), The Product Life Factor. An Inquiry into the Nature of Sustainable Societies: The Role of the Private Sector, Series: 1982 Mitchell Prize Papers, HARC, Houston.

Sterman, J.D. (2000), Business Dynamics. System Thinking and Modeling for a Complex World, McGraw-Hill, Boston.

Stewart, R. and Niero, M. (2018), "Circular economy in corporate sustainability strategies: a review of corporate sustainability reports in the fast-moving consumer goods sector", Business Strategy and the Environment, Vol. 27 No. 7, pp. 1005-1022.

Stubbs, W. and Higgins, C. (2014), "Integrated reporting and internal mechanisms of change", Accounting, Auditing and Accountability Journal, Vol. 27 No. 7, pp. 1068-1089.

Svensson, N. and Funck, E.K. (2019), "Management control in circular economy. Exploring and theorizing the adaptation of management control to circular business models", Journal of Cleaner Production, Vol. 233, pp. 390-398.

Tajbakhsh, A. and Hassini, E. (2015), "Performance measurement of sustainable supply chains: a review and research questions", International Journal of Productivity and Performance Management, Vol. 64 No. 6, pp. 744-783.

Ünal, E., Urbinati, A. and Chiaroni, D. (2019), "Managerial practices for designing circular economy business models", Journal of Manufacturing Technology Management, Vol. 30 No. 3, pp. 561-589.

UNEP-United Nations Environment Programme (2018), "Building circularity into our economies through sustainable procurement”, available at: http://apps.unep.org/repository/free-keywords/ circular-economy.

Velte, P. and Stawinoga, M. (2017), "Integrated reporting: the current state of empirical research, limitations and future research implications", Journal of Management Control, Vol. 28 No. 3, pp. 275-320.

Werning, J.P. and Spinler, S. (2020), "Transition to circular economy on firm level: barrier identification and prioritization along the value chain", Journal of Cleaner Production, Vol. 245, 118609 .

Wicks, P.G. and Reason, P. (2009), "Initiating action research: challenges and paradoxes of opening communicative space", Action Research, Vol. 7 No. 3, pp. 243-262.

Wilson, C. (2013), Brainstorming and beyond: A User-Centered Design Method, Morgan-Kaufman, Elsevier, Oxford.

Yin, R.K. (1994), Case Study Research: Design and Methods, 2nd ed., Sage, Newbury Park, CA.

Zhou, S., Simnett, R. and Green, W. (2017), "Does integrated reporting matter to the capital market?", Abacus, Vol. 53 No. 1, pp. 94-132.
Integrated reporting and circular economy 
IJPPM

70,8

$\mathbf{7 0 , 8}$

No. $\quad$ Organization

1. ABSA

2. $\quad$ Adapt It

3. Aegon

4. Aegon

Anglo Platinum

6. AngloGold Ashanti

Anance Academy

Aspiag Service S.R.L. Despar Nordest

BAE Systems

10. $\quad$ Barclays Africa Group

11. British American Tobacco

12. British American Tobacco

13. British Land

14. Browns and Company PLC

15. BT Group

16. Cbus

17. Cemex

18. Coca-Cola Hellenic Bottling Company

19. Crest Nicholson

20. DBS

21. DBS

22. DBSA

23. Dellas

24. Dentsu

25. DIMO

26. DIMO

27. DSM

28. DSM

29. Duchy Of Cornwall

30. enBW

31. EOH Holdings

32. Eskom

33. Eurazeo

34. Exxaro

35. FMO

36. Fresnillo

37. Fresnillo

38. Generali

39. Go-Ahead

40. Gold Fields

41. Gold Fields

42. Halfords

43.. Hammerson

$44 \quad$ Hulamin Ltd

45. Implats Platinum

46. ING

47. ING

48. Intercontinental Hotel Group

Table A1.

Characteristics of the dataset of organizations and documents used in this study

\begin{tabular}{lll} 
Year & Region & Business industry \\
\hline & & \\
2017 & Europe & Financial services \\
2017 & Africa & Technology \\
2016 & Europe & Financial services \\
2017 & Europe & Financial services \\
2016 & Africa & Basic Materials \\
2016 & Europe & Basic material \\
2016 & Europe & Professional Services \\
2017 & Europe & Industrials \\
2017 & Africa & Financial services \\
2017 & Europe & Consumer Services \\
2015 & Europe & Consumer services \\
2017 & Europe & Financial services \\
2017 & Asia & Consumer goods \\
2017 & Europe & Telecommunications \\
2017 & Australasia & Public sector \\
2017 & North America & Industrials \\
2016 & Europe & Consumer goods \\
2016 & Europe & Real estate \\
2017 & Asia & Financial services \\
2016 & Asia & Financial Services \\
2016 & Africa & Financial services \\
2016 & Europe & Industrial \\
2017 & Asia & Consumer services \\
2017 & Asia & Industrials \\
2013 & Asia & Industrials \\
2017 & Europe & Healthcare \\
2016 & Europe & Healthcare \\
2017 & Europe & Real estate \\
2017 & Europe & Utilities \\
2016 & Africa & Technology \\
2017 & Africa & Utilities \\
2016 & Europe & Financial services \\
2017 & Africa & Basic materials \\
2017 & Europe & Financial services \\
2016 & Europe & Basic Materials \\
2014 & Europe & Basic materials \\
2017 & Europe & Financial services \\
2017 & Europe & Consumer services \\
2017 & Africa & Basic materials \\
2016 & Africa & Basic materials \\
2017 & Europe & Consumer services \\
2014 & Europe & Financial services \\
2016 & Africa & Industrials \\
2017 & Africa & Basic materials \\
2016 & Europe & Financial services \\
2015 & Europe & Financial services \\
2017 & Europe & Consumer services \\
2017 & South America & Financial services \\
2016 & South America & Financial services \\
2017 & Africa & Basic materials \\
2017 & Australasia & Real estate \\
& & \\
\hline
\end{tabular}

(continued) 


\begin{tabular}{|c|c|c|c|c|c|}
\hline No. & Organization & Year & Region & Business industry & $\begin{array}{l}\text { Integrated } \\
\text { renortino and }\end{array}$ \\
\hline 53. & Lloyds Banking Group & 2017 & Europe & Financial services & circular \\
\hline 54. & Marks and Spencer & 2017 & Europe & Consumer goods & \\
\hline 55. & Marui Group & 2016 & Asia & Consumer service & economy \\
\hline 56. & Mediclinic & 2017 & Europe & Healthcare & \\
\hline 57. & Meridian Energy & 2017 & Australasia & Utilities & \\
\hline 58. & Mitusi and $\mathrm{Co}_{0}$ & 2016 & Asia & Financial services & 2027 \\
\hline 59. & MTN Group & 2017 & Africa & Telecommunications & \\
\hline 60. & Nedbank & 2016 & Africa & Financial services & \\
\hline 61. & Novo Nordisk & 2016 & Europe & Healthcare & \\
\hline 62. & Peoples Leasing and Finance & 2016 & Asia & Financial services & \\
\hline 63. & Redefine Properties & 2016 & Africa & Real estate & \\
\hline 64. & Rosneft & 2017 & Asia & Oil and gas & \\
\hline 65. & Royal Bafokeng Platinum Ltd & 2017 & Africa & Basic materials & \\
\hline 66. & Royal Bafokeng Platinum Ltd & 2016 & Africa & Basic material & \\
\hline 67. & Sage & 2014 & Europe & Technology & \\
\hline 68. & SAICA & 2016 & Africa & Professional services & \\
\hline 69. & Sanford & 2017 & Australasia & Consumer goods & \\
\hline 70. & Sanlam Ltd. & 2015 & Africa & Financial services & \\
\hline 71. & Santova Ltd & 2017 & Africa & Professional services & \\
\hline 72. & Stafer & 2016 & Europe & Industrials & \\
\hline 73. & Standard Bank Group Ltd & 2016 & Africa & Financial services & \\
\hline 74. & Strate & 2017 & Africa & Financial services & \\
\hline 75. & Talawakelle Tea Estates & 2016 & Asia & Consumer goods & \\
\hline 76. & Tata Steel & 2016 & Asia & Industrials & \\
\hline 77. & The Crown Estate & 2018 & Europe & Real estate & \\
\hline 78. & Transnet & 2017 & Africa & Consumer services & \\
\hline 79. & Truworths & 2017 & Africa & Consumer goods & \\
\hline 80. & United Utilities & 2017 & Europe & Utilities & \\
\hline 81. & Vodacom & 2017 & Africa & Telecommunications & \\
\hline 82. & Vodafone & 2011 & Europe & Telecommunications & \\
\hline 83. & Waco International & 2016 & Africa & Industrials & \\
\hline 84. & York Timbers Pty Ltd & 2017 & Africa & Basic materials & Table A1. \\
\hline
\end{tabular}




\section{IJPPM}

70,8

\section{8}

Table A2.

Results of content analysis for the category "Industry"

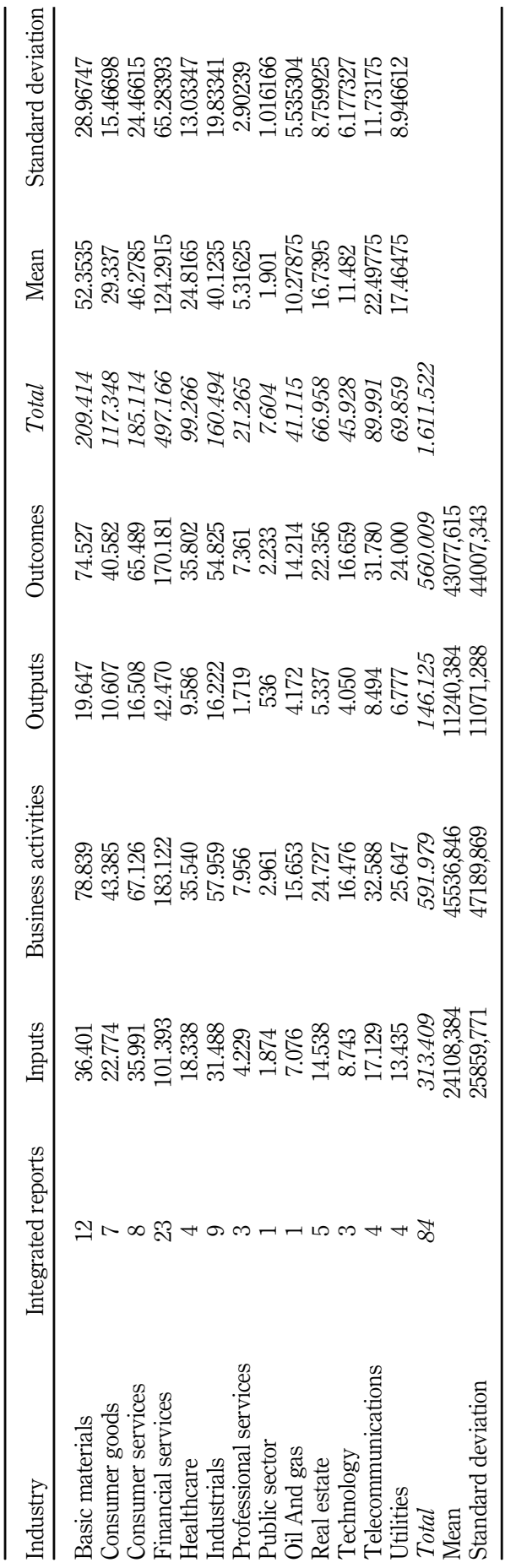




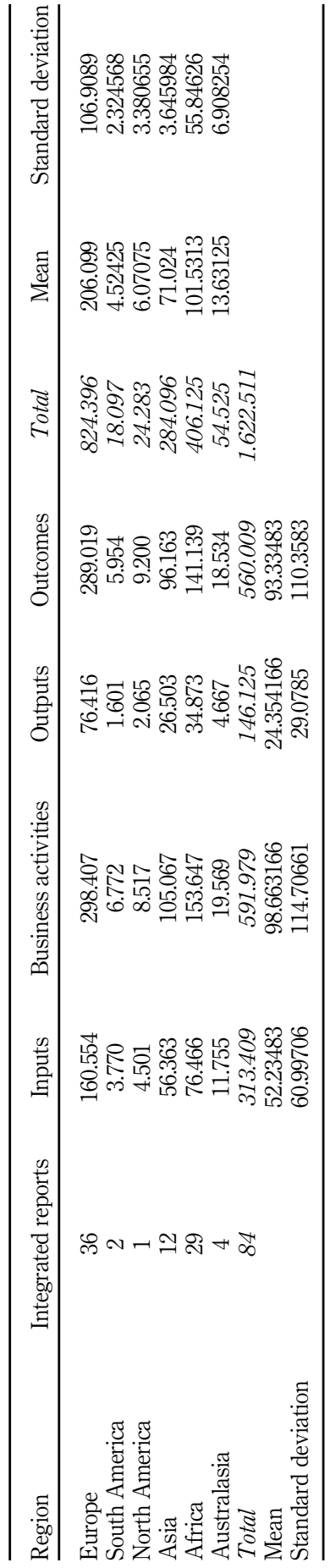

Integrated reporting and circular economy

2029

Table A3.

Results of content analysis for the category "Region" 


\section{IJPPM}

70,8

\section{0}

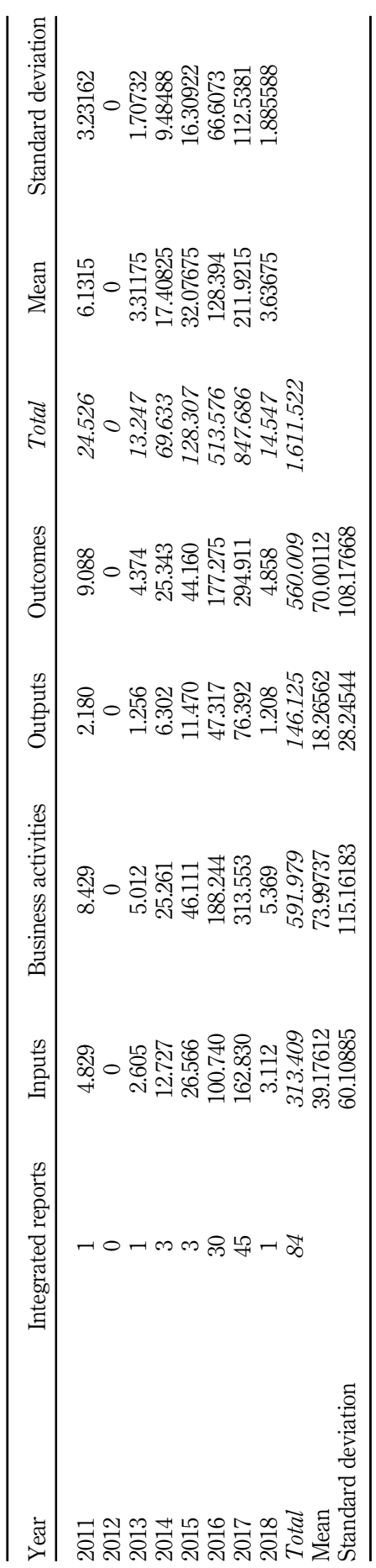

Table A4.

Results of content analysis for the category "Year" 


\section{About the authors}

Federico Barnabè, Ph.D., is Associate Professor in Business Administration at the Department of Business and Law, University of Siena (Italy). Previously, Federico was a visiting researcher at the University of Bergen (Norway) and Roehampton University (UK). His main research interests include Management Accounting, Performance Measurement, and Simulation and Gaming (with particular reference to System Dynamics). He published in several international journals on these topics. Federico Barnabè is the corresponding author and can be contacted at: barnabe@unisi.it

Sarfraz Nazir holds a M.Sc. in Management and Governance and is a Ph.D. candidate at the University of Pisa (Italy). Currently, he is a visiting scholar at the University of Portsmouth (UK). His main research interests include management accounting and performance management in the field of sustainability reporting and circular economy.

For instructions on how to order reprints of this article, please visit our website: 